Supporting Information

\title{
Synthesis of Functionalized 6,5- and 7,5-Azabicycloalkane Amino Acids by
}

\section{Metathesis Reactions}

Massimo Serra*, Eric Bernardi, Ersilia De Lorenzi, and Lino Colombo

Department of Drug Sciences, Medicinal Chemistry and Pharmaceutical Technology Section, University of Pavia, Viale Taramelli 12, 27100 Pavia, Italy

E-mail: massimo.serra@unipv.it

\section{Table of Contents}

S2 Copies of ${ }^{1} \mathrm{H}$ NMR (400 MHz), ${ }^{13} \mathrm{C}$ NMR and DEPT 135 spectra for compound $\mathbf{5 b}$

S3 Copies of ${ }^{1} \mathrm{H}$ NMR (400 MHz), ${ }^{13} \mathrm{C}$ NMR and DEPT 135 spectra for compound 6a

S4 Copies of ${ }^{1} \mathrm{H}$ NMR (400 MHz), ${ }^{13} \mathrm{C}$ NMR and DEPT 135 spectra for compound $\mathbf{6 b}$

S5 Copies of ${ }^{1} \mathrm{H}$ NMR (400 MHz), ${ }^{13} \mathrm{C}$ NMR and DEPT 135 spectra for compound 8a

S6 Copies of ${ }^{1} \mathrm{H}$ NMR (400 MHz), ${ }^{13} \mathrm{C}$ NMR and DEPT 135 spectra for compound $\mathbf{8 b}$

S7 Copies of ${ }^{1} \mathrm{H}$ NMR (400 MHz), ${ }^{13} \mathrm{C}$ NMR and DEPT 135 spectra for compound 12a

S8 Copies of ${ }^{1} \mathrm{H}$ NMR (400 MHz), ${ }^{13} \mathrm{C}$ NMR and DEPT 135 spectra for compound $\mathbf{1 2 b}$

S9 Copies of ${ }^{1} \mathrm{H}$ NMR (400 MHz), ${ }^{13} \mathrm{C}$ NMR and DEPT 135 spectra for compound 13a

S10 Copies of ${ }^{1} \mathrm{H}$ NMR (400 MHz), ${ }^{13} \mathrm{C}$ NMR and DEPT 135 spectra for compound 14a

S11 Copies of ${ }^{1} \mathrm{H}$ NMR (400 MHz), ${ }^{13} \mathrm{C}$ NMR, DEPT 135, 2D-COSY, and 2D-NOESY spectra for compound 15a

S14 Copies of ${ }^{1} \mathrm{H}$ NMR (400 MHz), ${ }^{13} \mathrm{C}$ NMR, DEPT 135, 2D-COSY, and 2D-NOESY spectra for compound 16ad

S17 Copies of ${ }^{1} \mathrm{H}$ NMR (400 MHz), ${ }^{13} \mathrm{C}$ NMR, DEPT 135, 2D-COSY, 2D-NOESY, 2DHMQC, and 2D-HMBC spectra for compound 16au

S21 Copies of ${ }^{1} \mathrm{H}$ NMR (400 MHz), ${ }^{13} \mathrm{C}$ NMR, DEPT 135, 2D-COSY, 2D-NOESY, and 2DHMQC spectra for compound 18a

S25 Copies of ${ }^{1} \mathrm{H}$ NMR (400 MHz), ${ }^{13} \mathrm{C}$ NMR and DEPT 135 spectra for side product I

S26 Copies of ${ }^{1} \mathrm{H}$ NMR (400 MHz), ${ }^{13} \mathrm{C}$ NMR and DEPT 135 spectra for side product II 
${ }^{1} \mathrm{H}$ NMR (400 MHz), ${ }^{13} \mathrm{C}$ NMR and DEPT 135 spectra of compound $5 \mathrm{~b}$
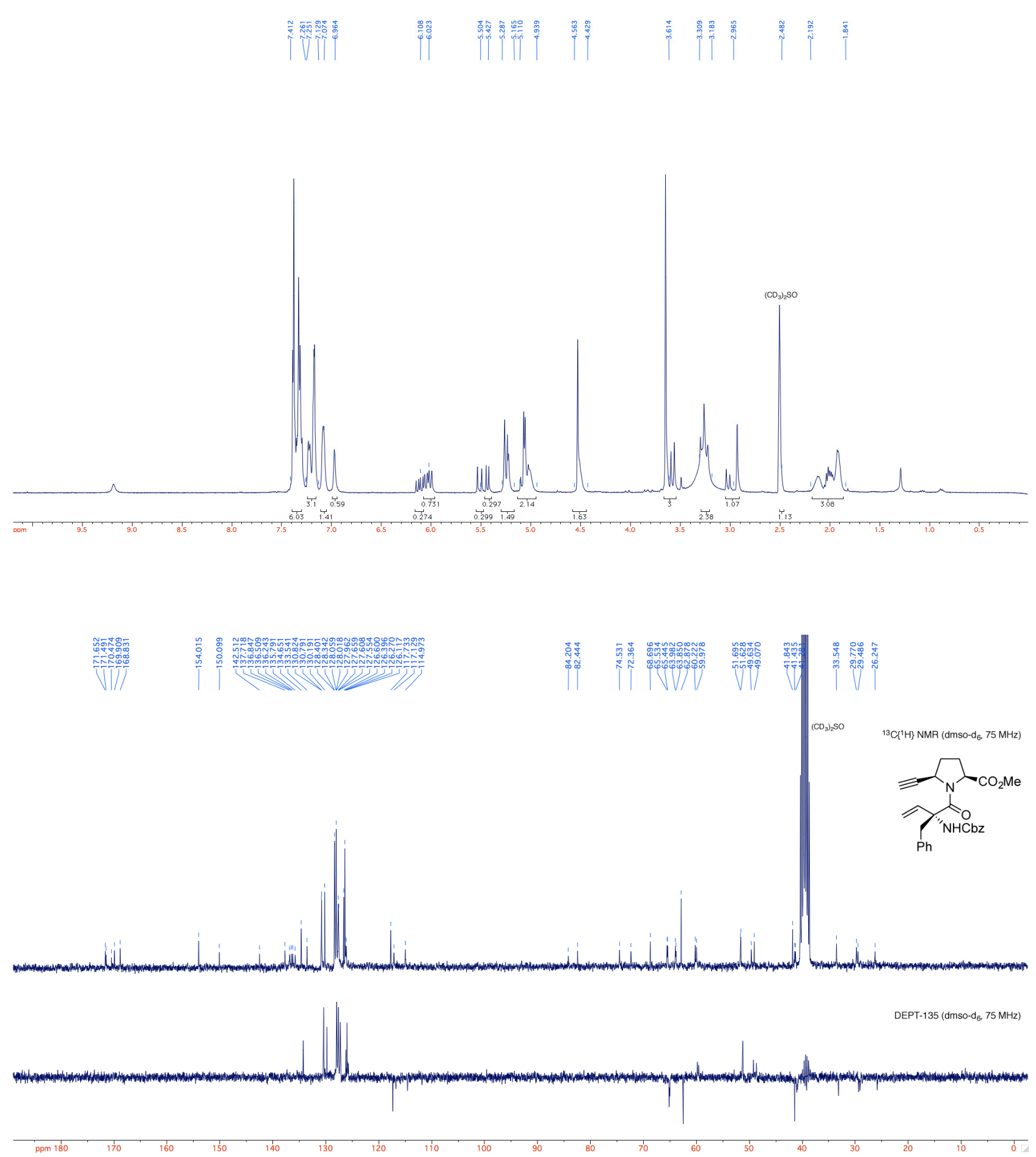
${ }^{1} \mathrm{H}$ NMR (400 MHz), ${ }^{13} \mathrm{C}$ NMR and DEPT 135 spectra of compound $6 a$
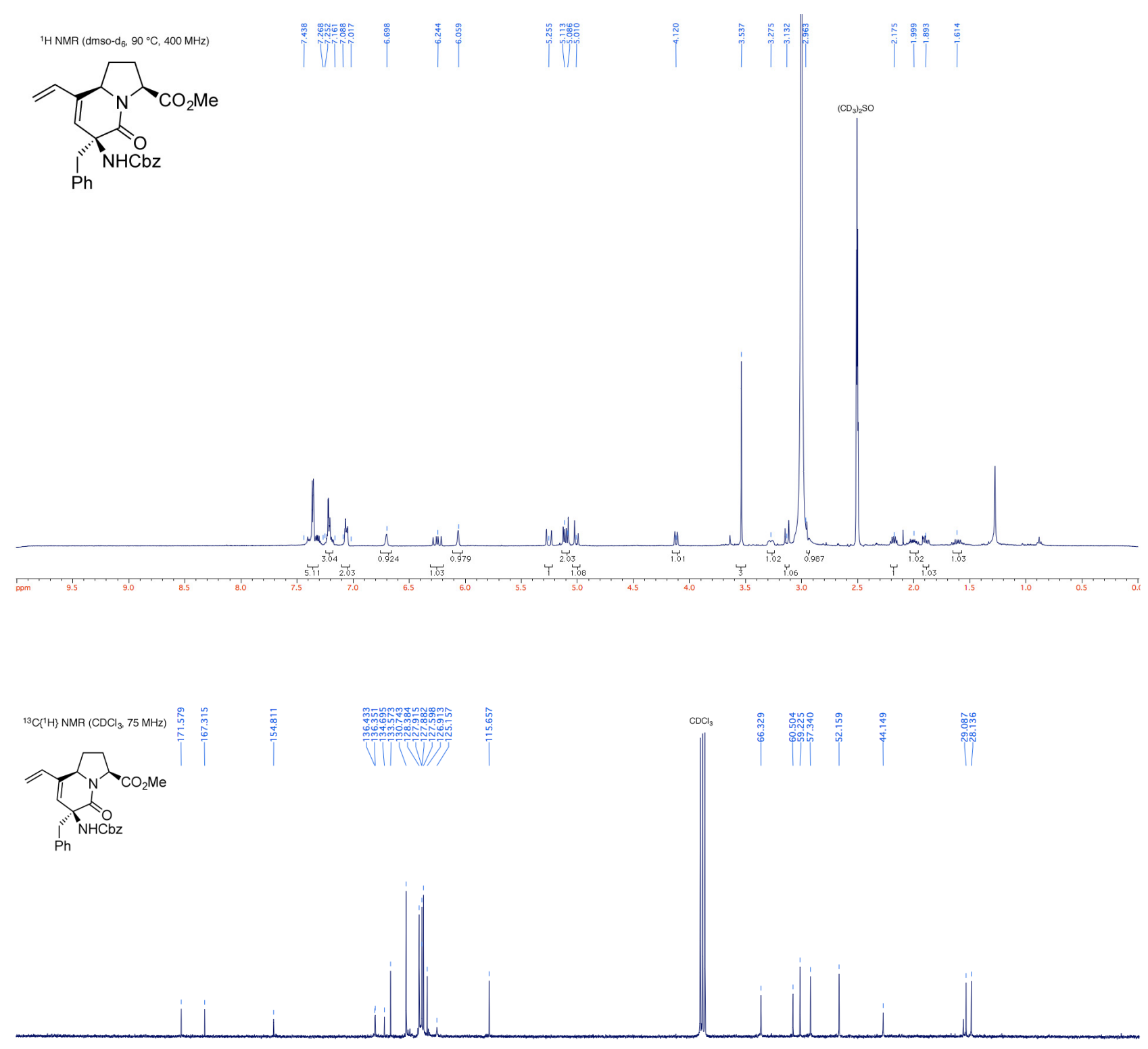

$\mathrm{DEPT}-135\left(\mathrm{CDCl}_{3}, 75 \mathrm{MHz}\right)$

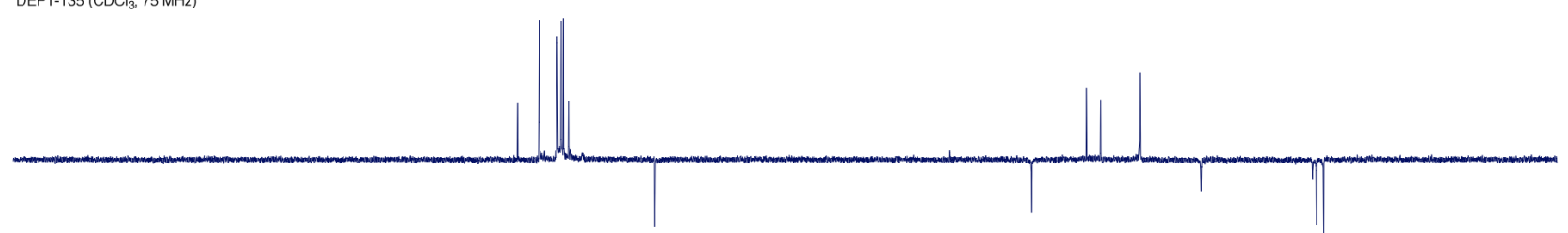

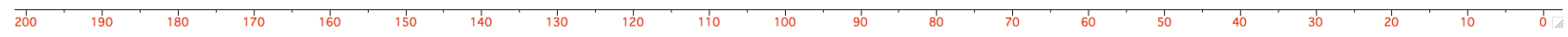


${ }^{1} \mathrm{H}$ NMR (400 MHz), ${ }^{13} \mathrm{C}$ NMR and DEPT 135 spectra of compound $6 \mathrm{~b}$
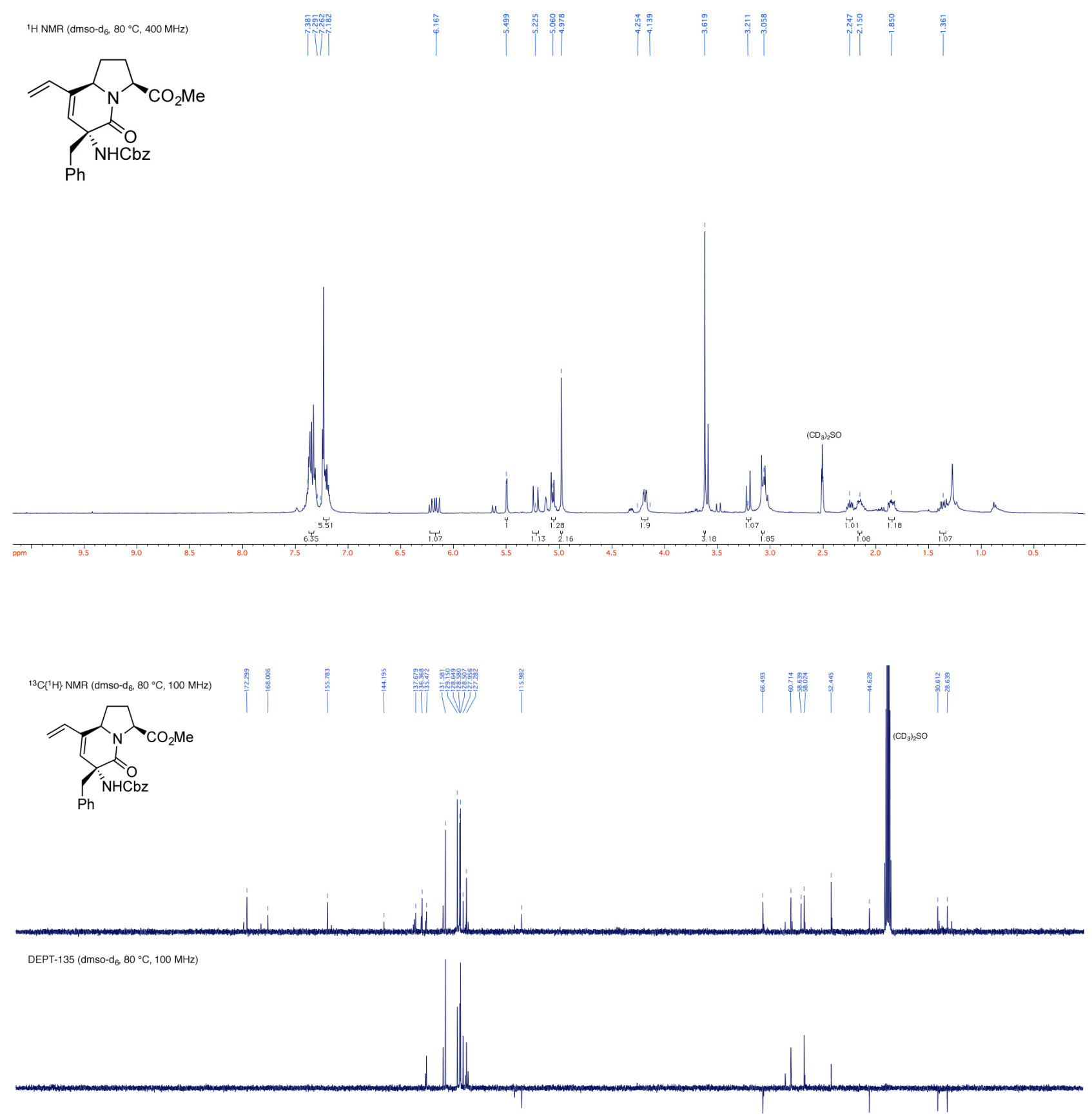
${ }^{1} \mathrm{H}$ NMR (400 MHz), ${ }^{13} \mathrm{C}$ NMR and DEPT 135 spectra of compound $8 \mathrm{a}$
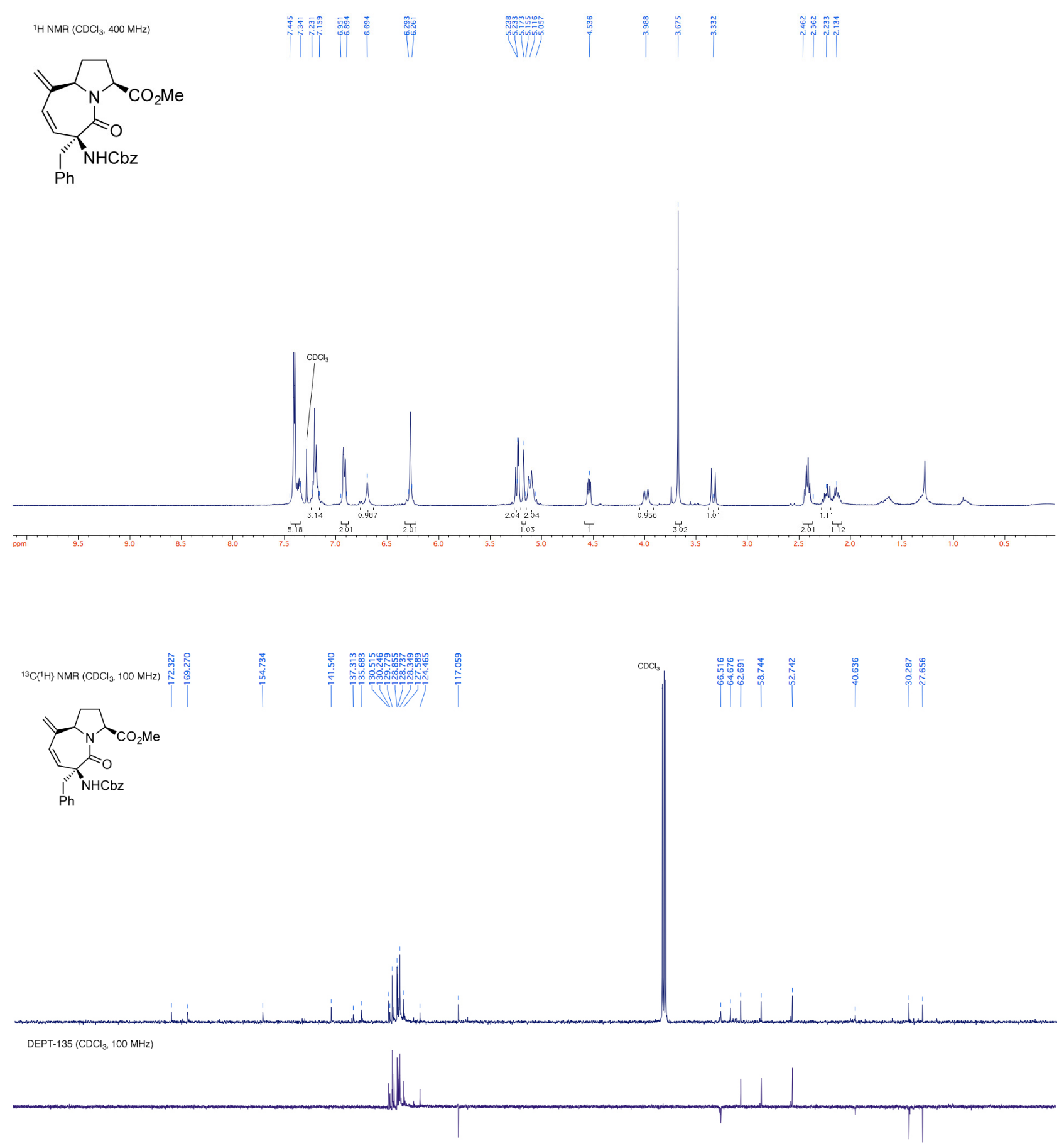

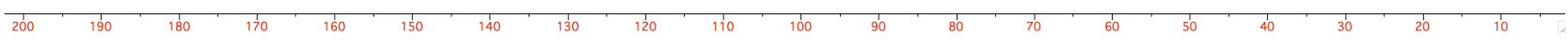


${ }^{1} \mathrm{H}$ NMR (400 MHz), ${ }^{13} \mathrm{C}$ NMR and DEPT 135 spectra of compound $8 \mathrm{~b}$
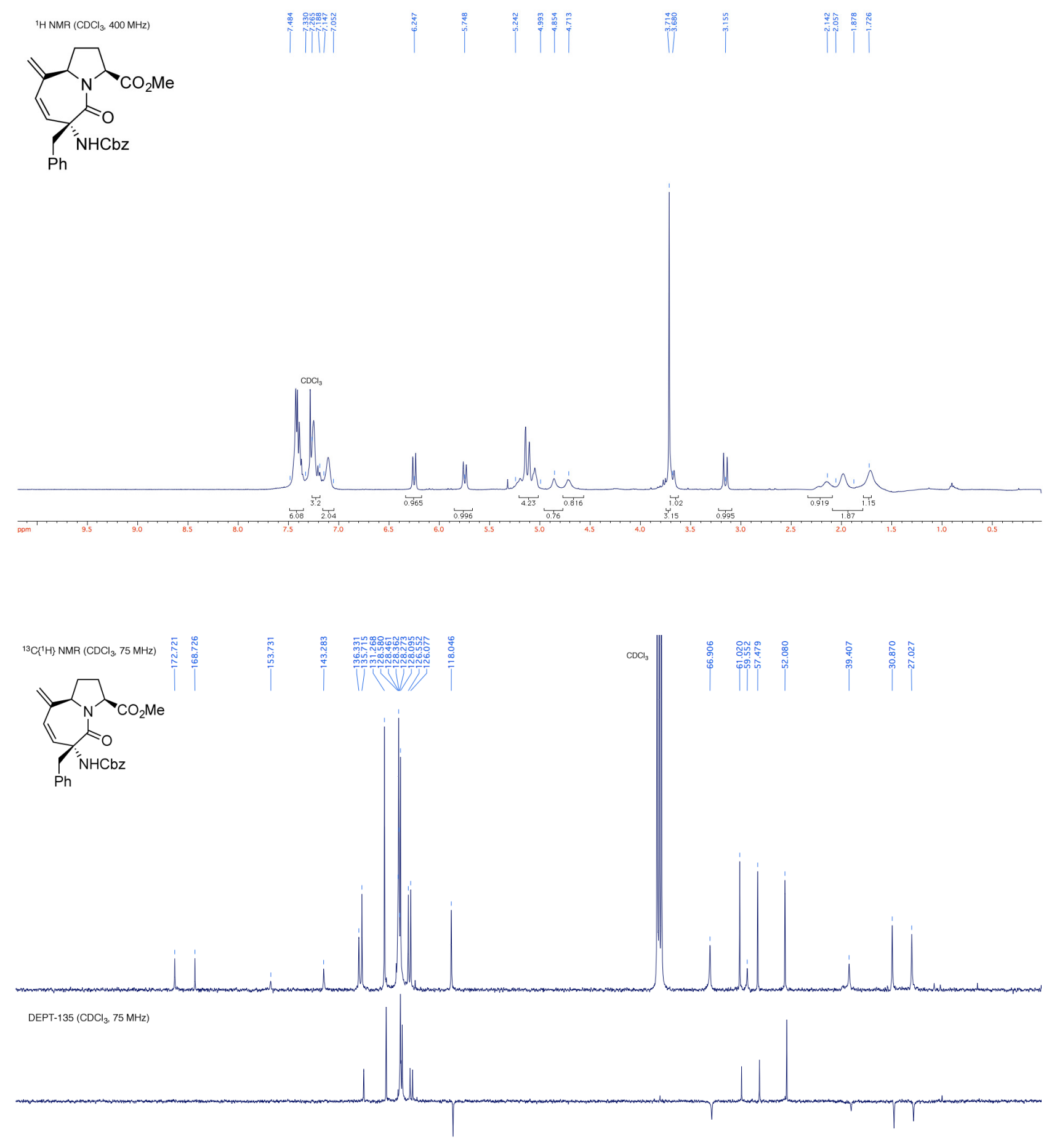
${ }^{1}$ H NMR (400 MHz), ${ }^{13} \mathrm{C}$ NMR and DEPT 135 spectra of compound 12a
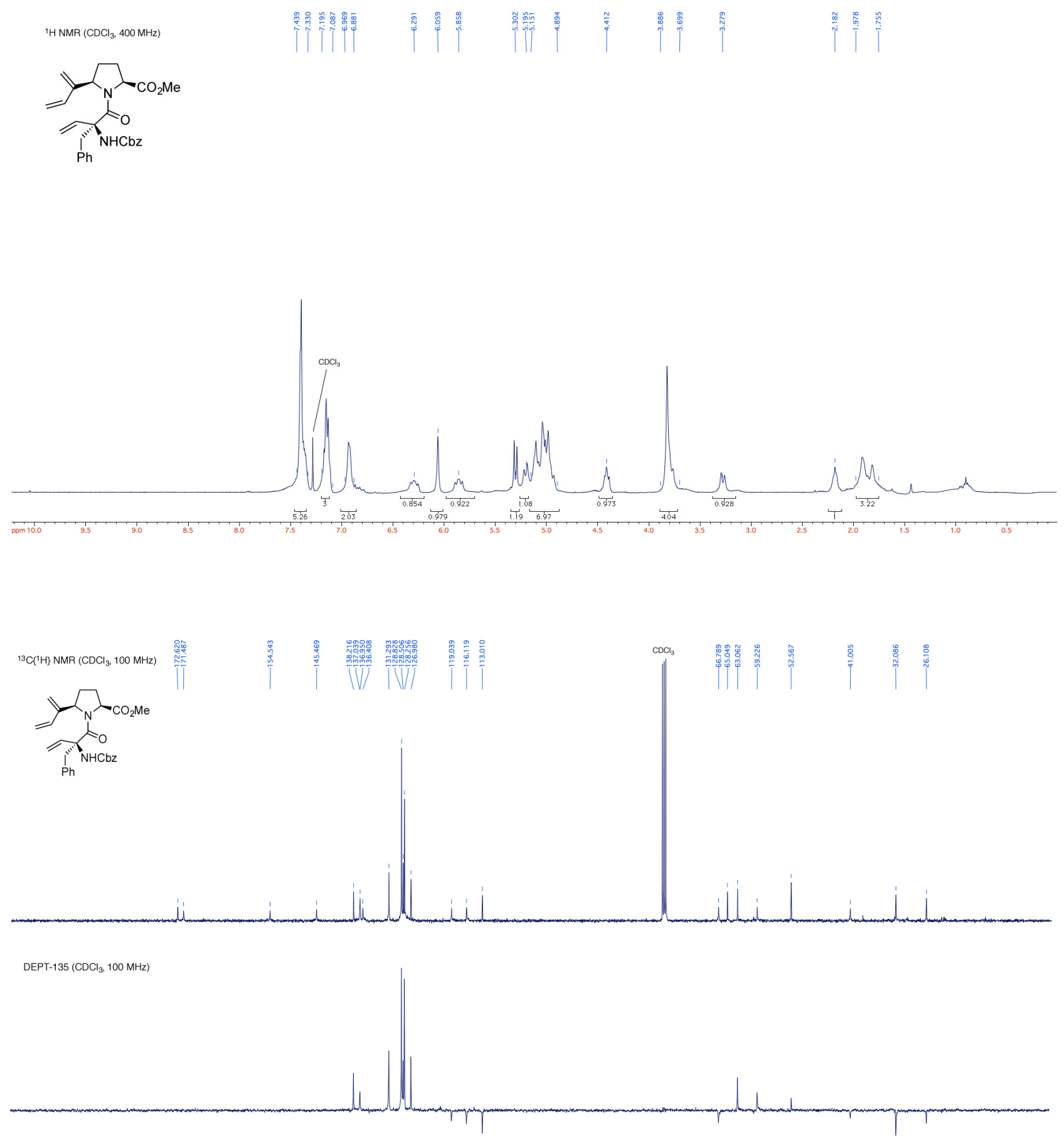

$\overbrace{\operatorname{ppm} 200}^{1}$ 
${ }^{1}$ H NMR (400 MHz), ${ }^{13} \mathrm{C}$ NMR and DEPT 135 spectra of compound 12b
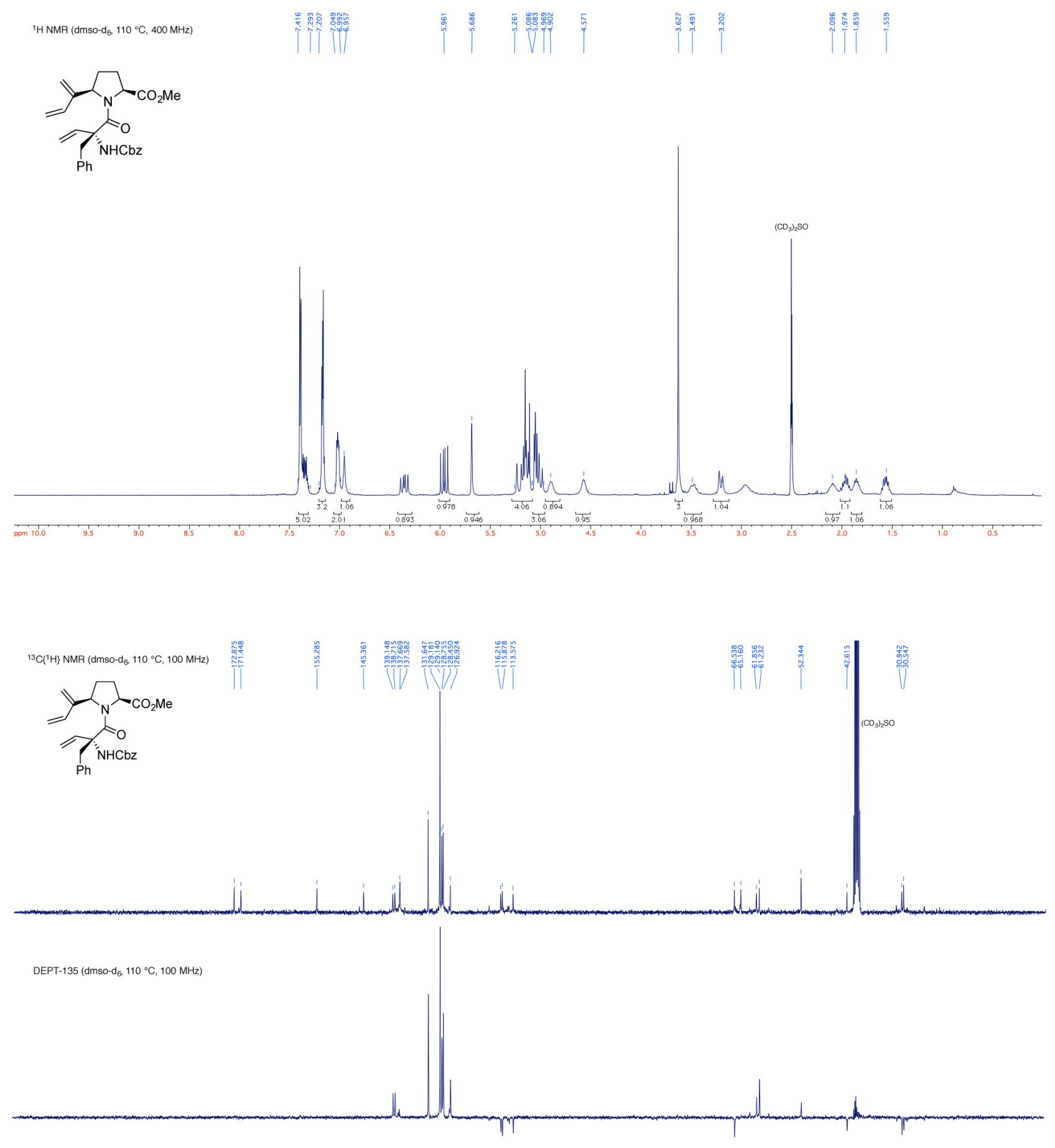
${ }^{1} \mathrm{H}$ NMR (400 MHz), ${ }^{13} \mathrm{C}$ NMR and DEPT 135 spectra of compound 13a
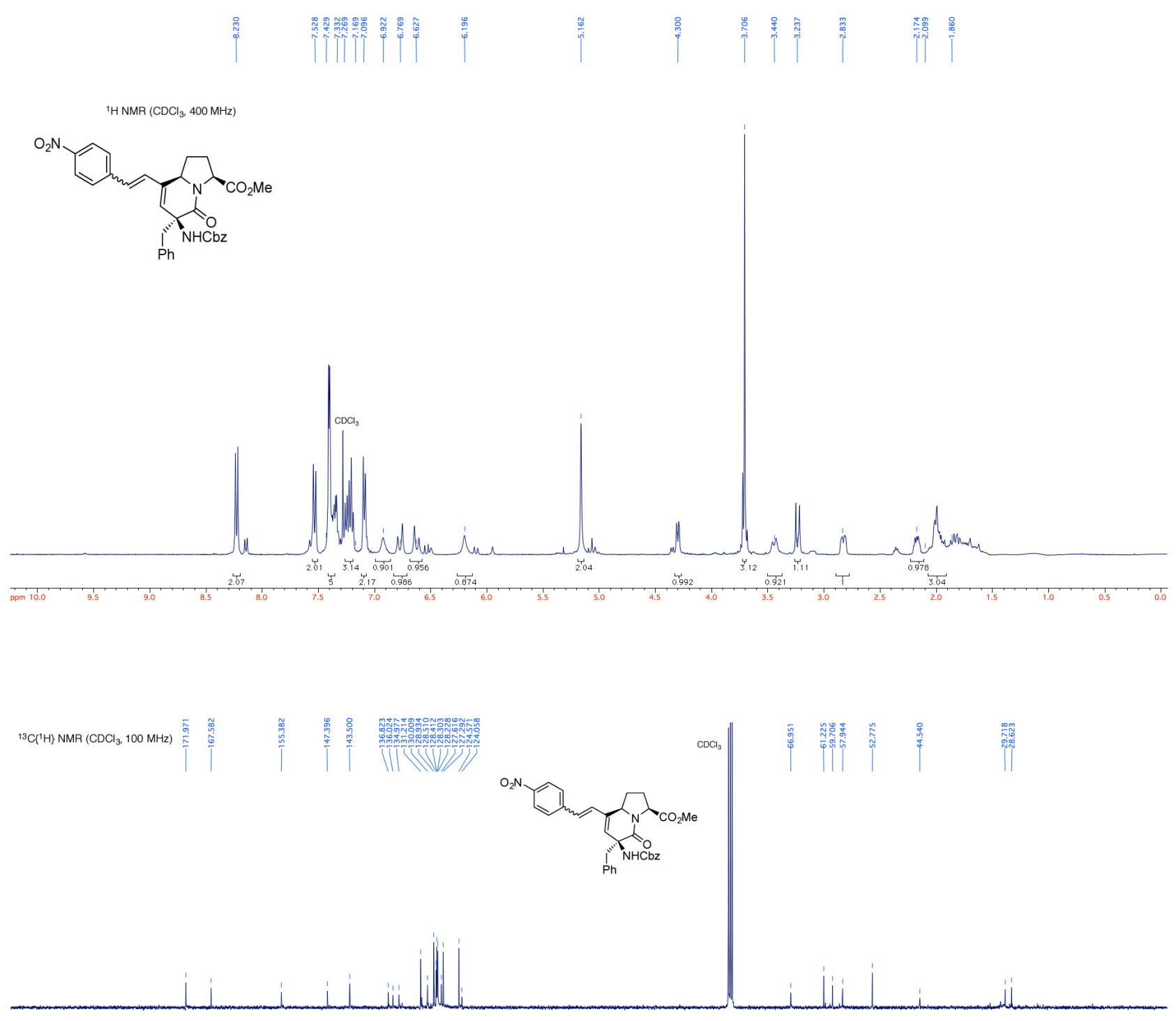

DEPT -135 $\left(\mathrm{CDCl}_{3}, 100 \mathrm{MHz}\right)$
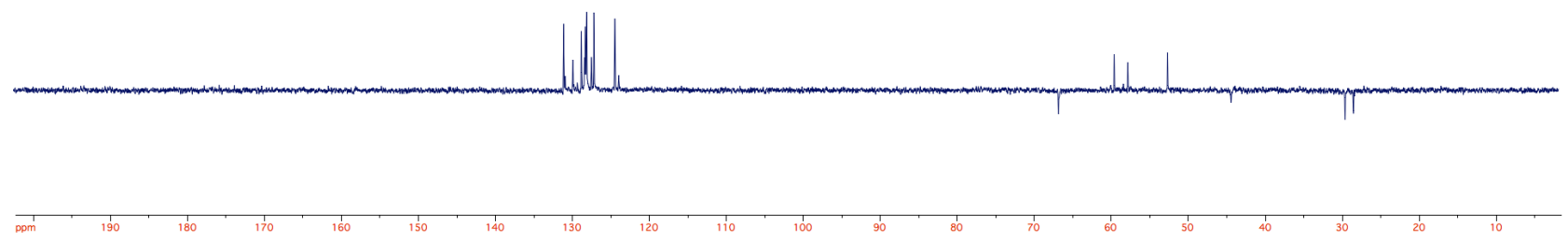

Sq 
${ }^{1}$ H NMR (400 MHz), ${ }^{13} \mathrm{C}$ NMR and DEPT 135 spectra of compound 14a

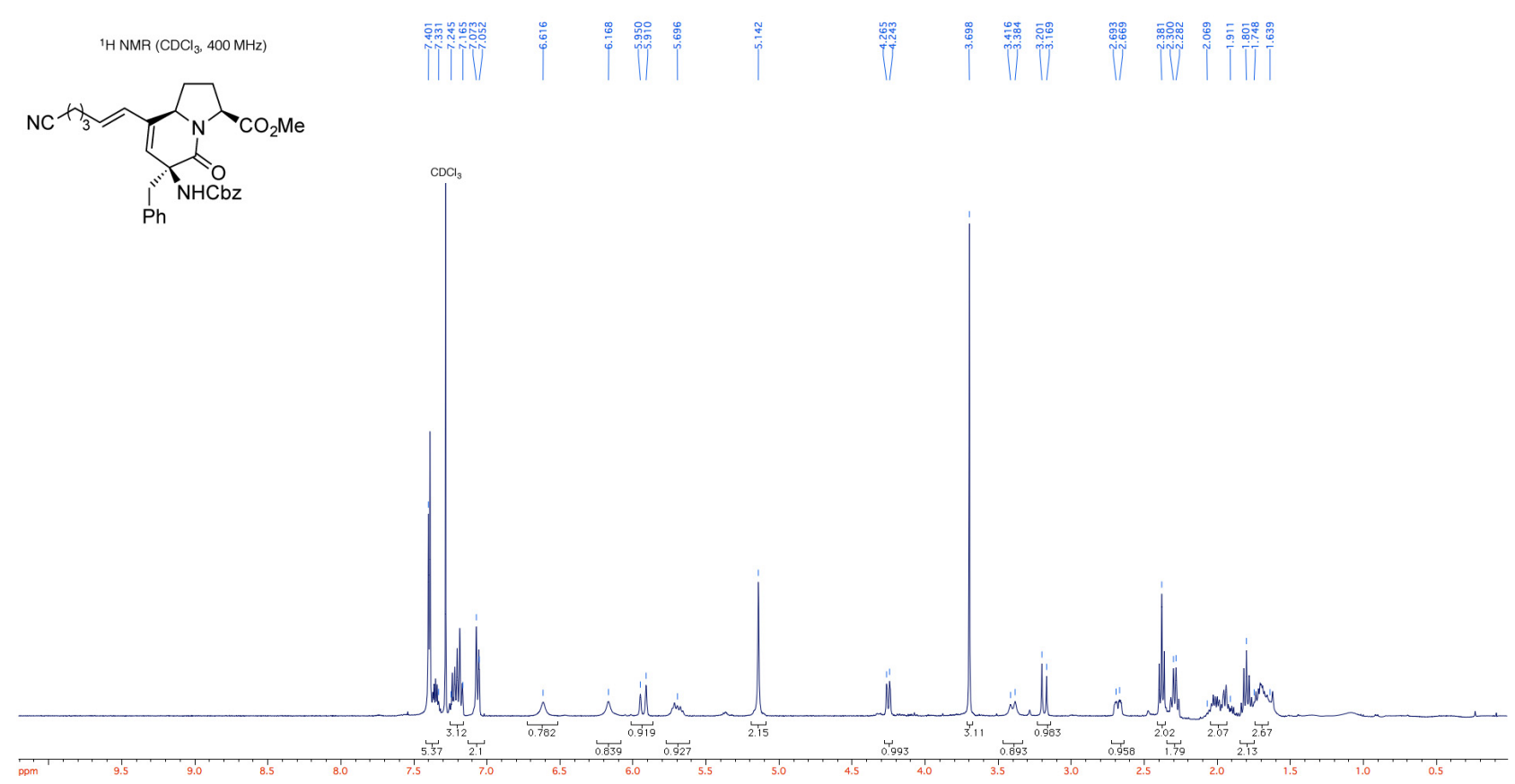

11
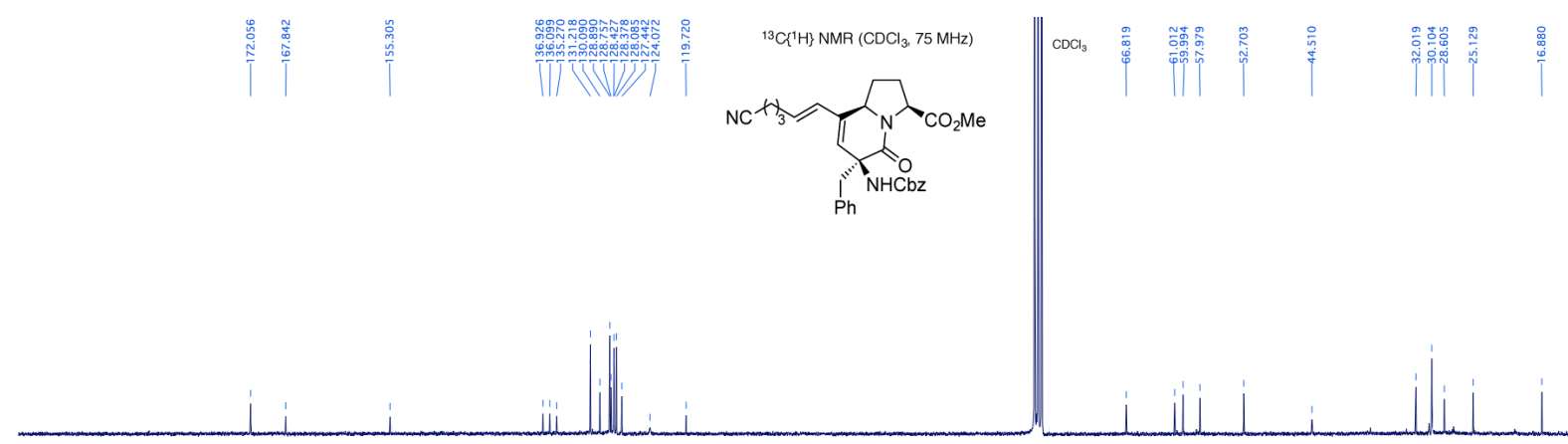

DEPT-135 (CDCl $13,75 \mathrm{MHz})$ 
${ }^{1} \mathrm{H}$ NMR (400 MHz), ${ }^{13} \mathrm{C}$ NMR, DEPT 135, 2D-COSY, and 2D-NOESY spectra of compound 15a
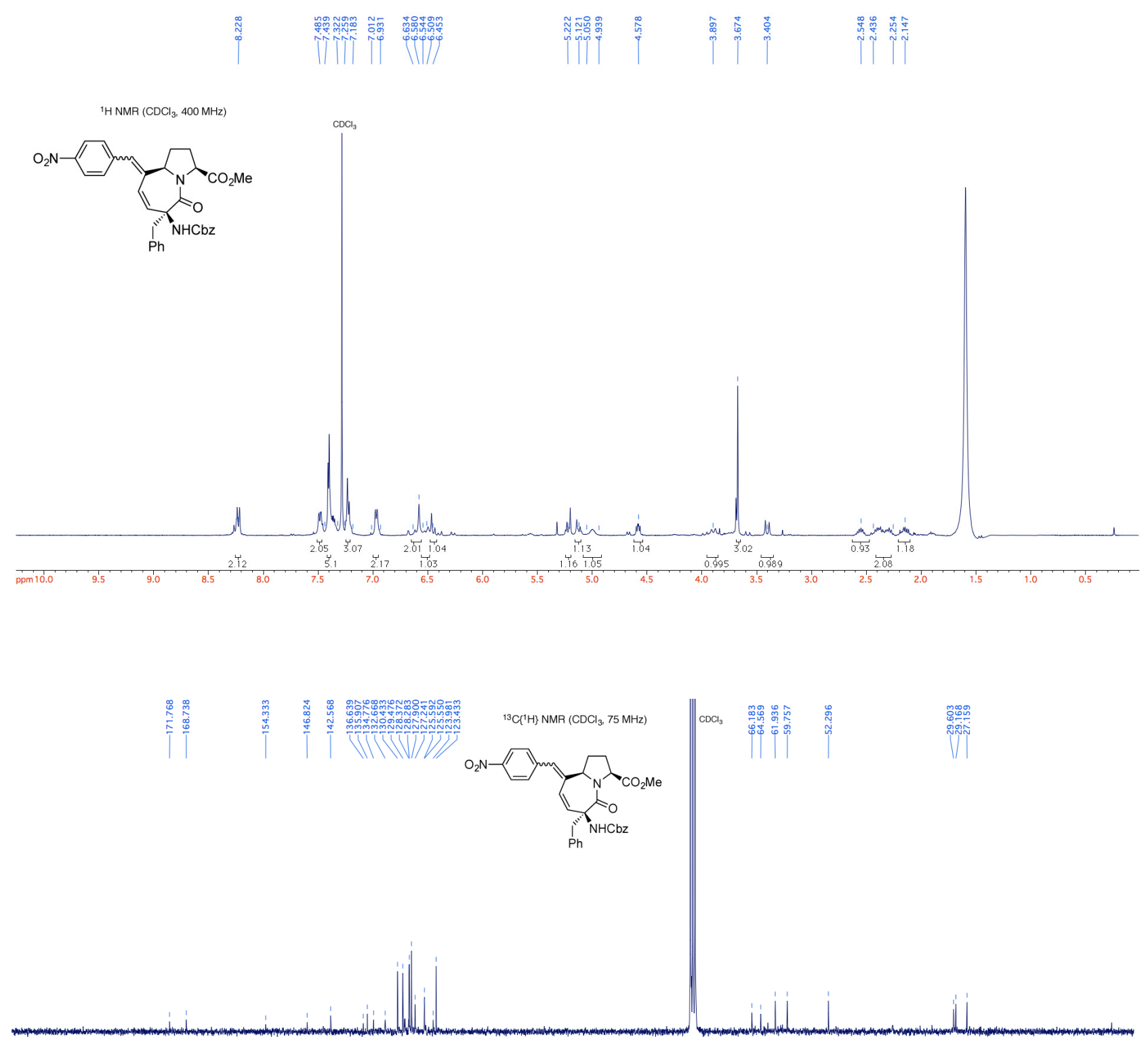

DEPT-135 ( $\left.\mathrm{CDCl}_{3}, 75 \mathrm{MHz}\right)$
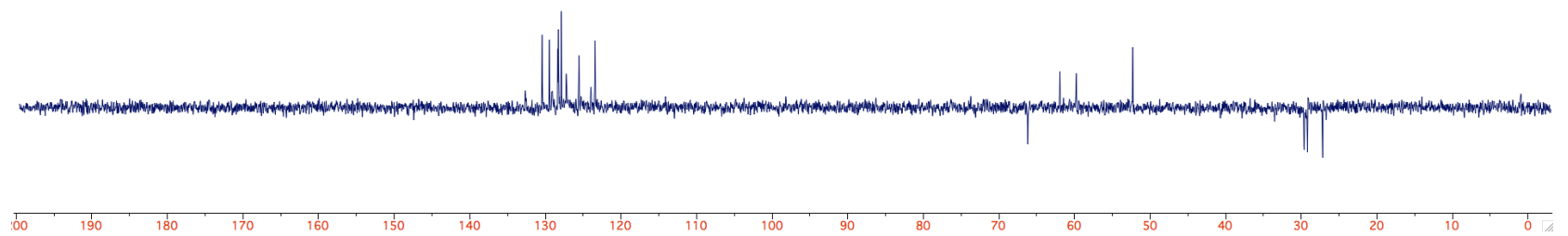

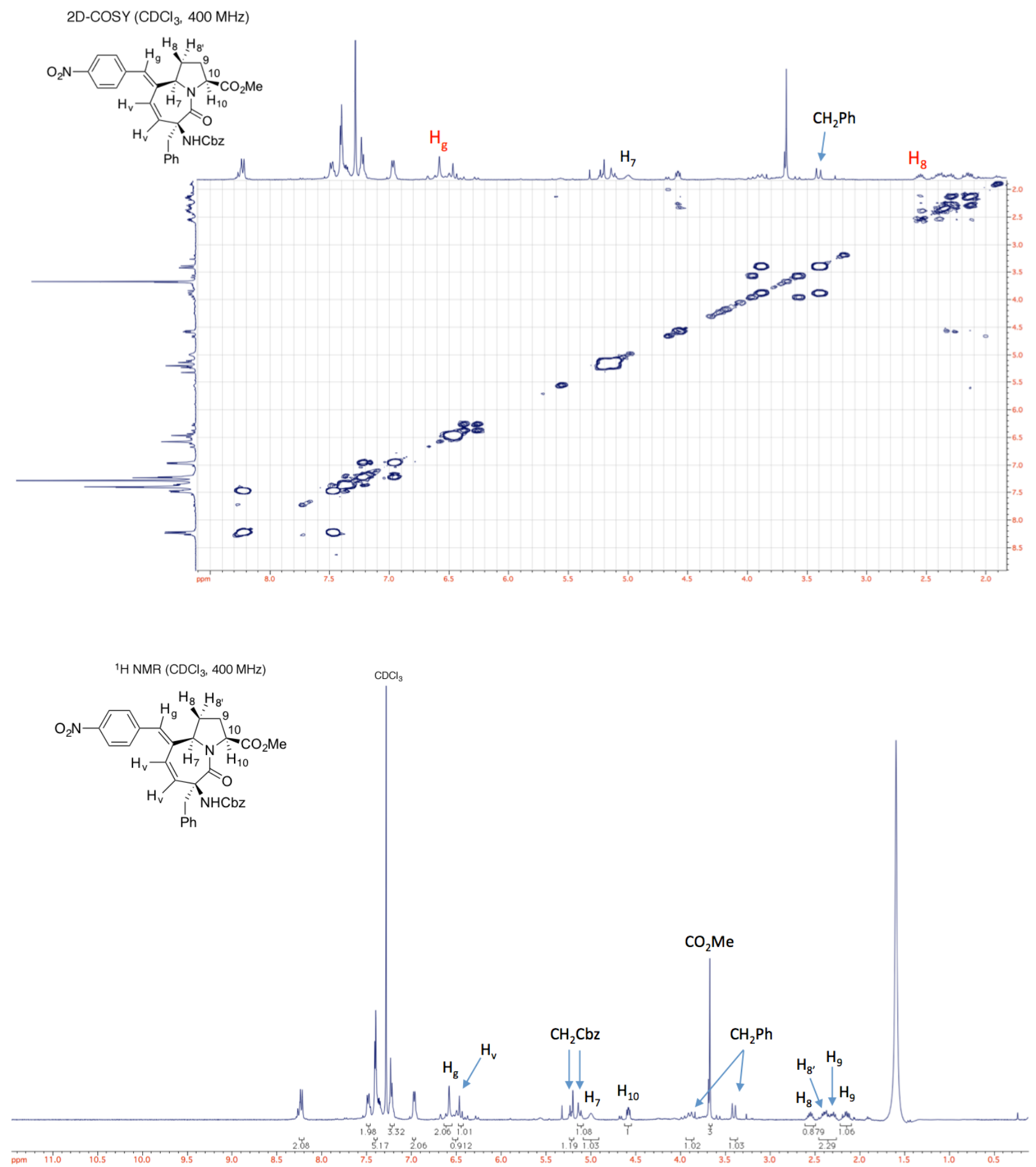


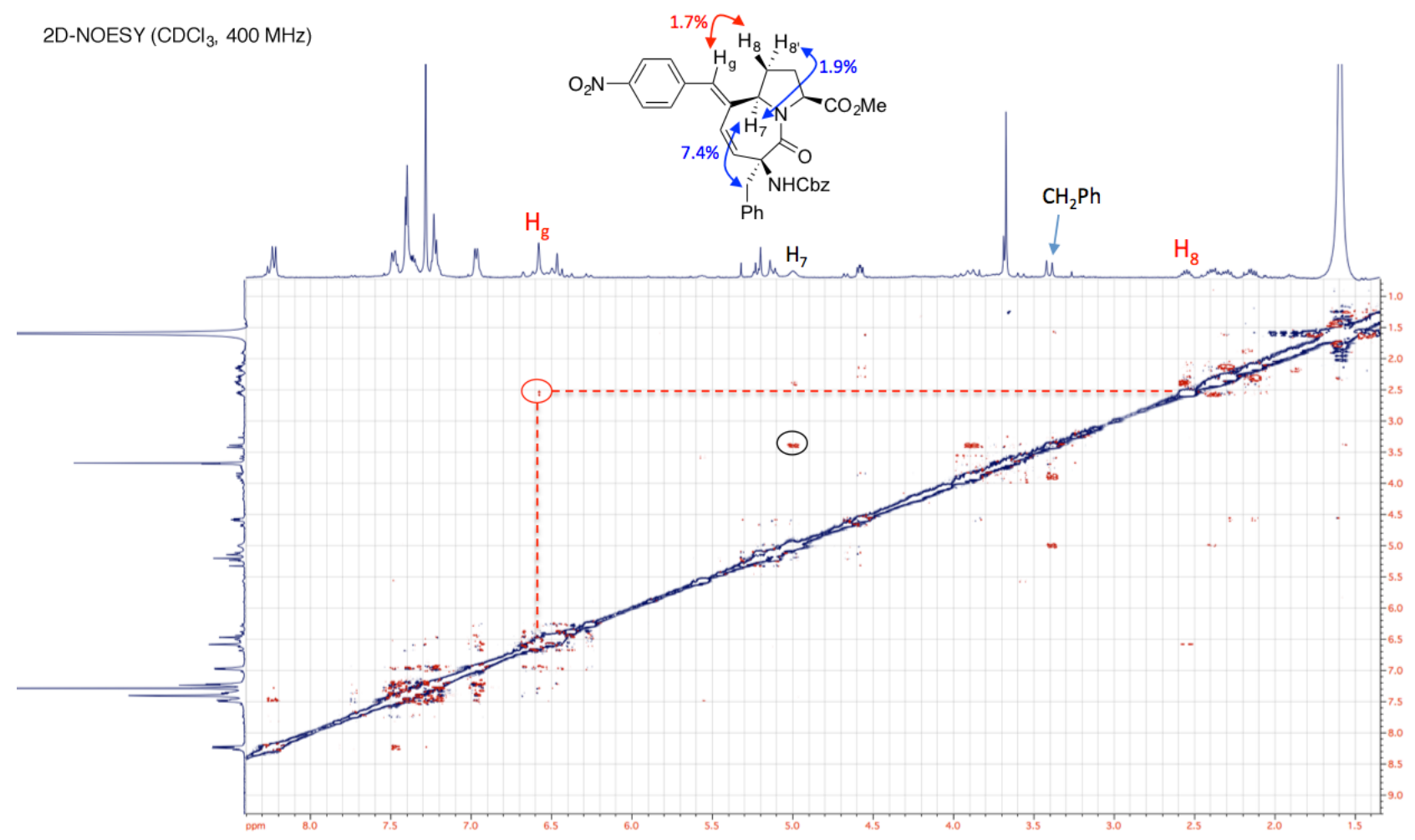

Curved arrows: NOESY correlations observed for 15a.

The strong magnetization transfer between $\mathrm{H}_{7}$ and one of the benzylic protons allowed to verify the absolute $R$-configuration at the ring fusion carbon. Diagnostic for the $E$-configuration of the exocyclic double bond (major stereoisomer) is the presence of an NOE between $\mathrm{H}_{\mathrm{g}}$ and $\mathrm{H}_{8}$. 
${ }^{1} \mathrm{H}$ NMR (400 MHz), ${ }^{13} \mathrm{C}$ NMR, DEPT 135, 2D-COSY, and 2D-NOESY spectra of compound 16ad

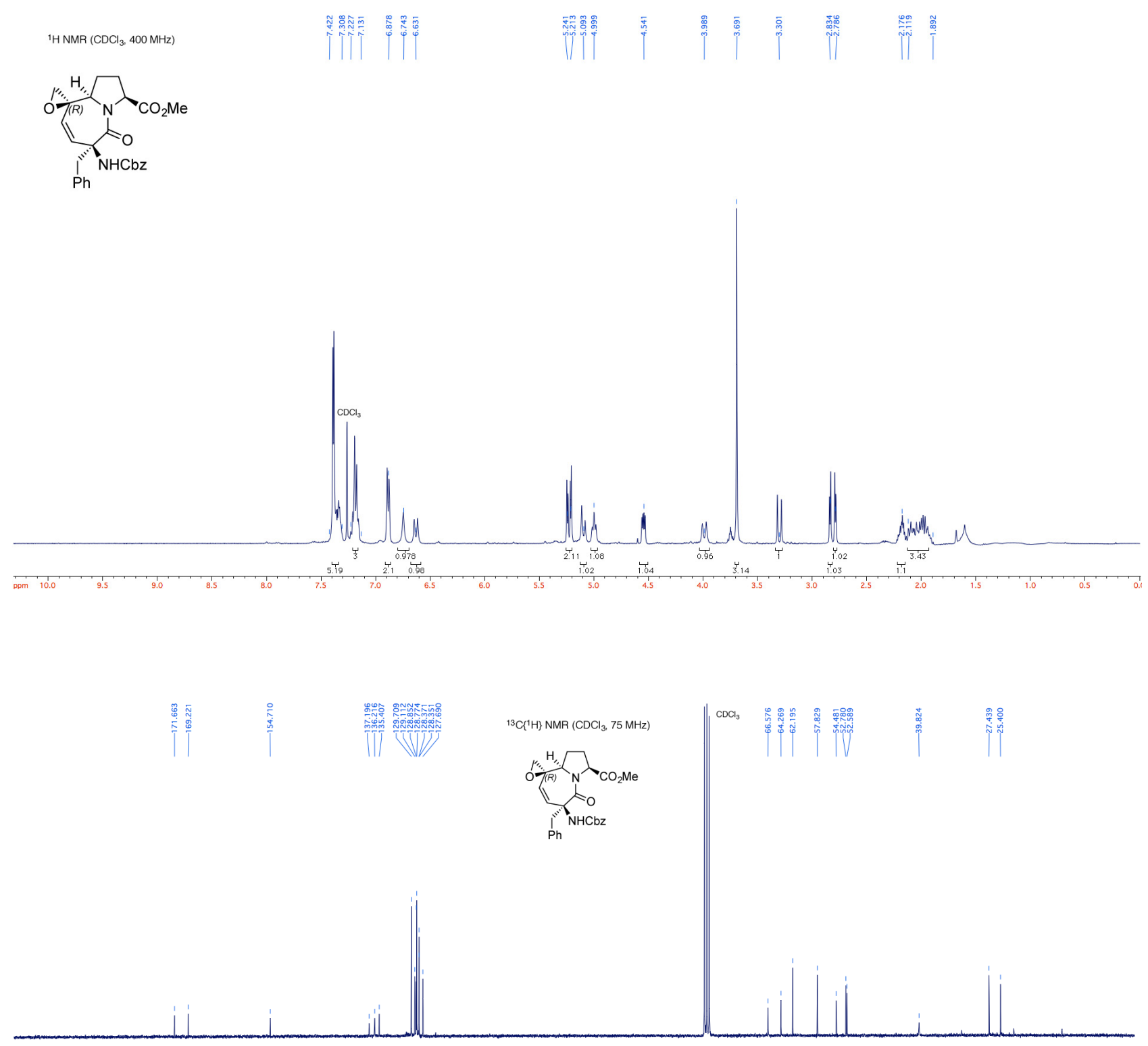

DEPT-135 (CDCl $3.75 \mathrm{MHz})$

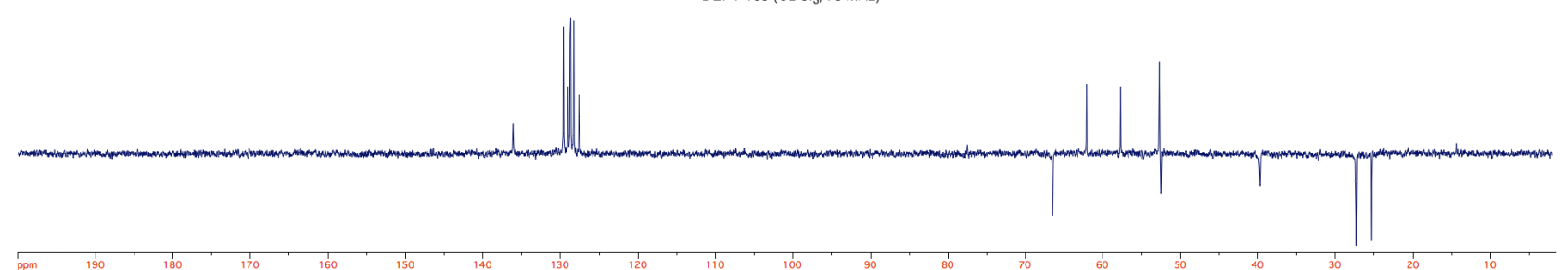




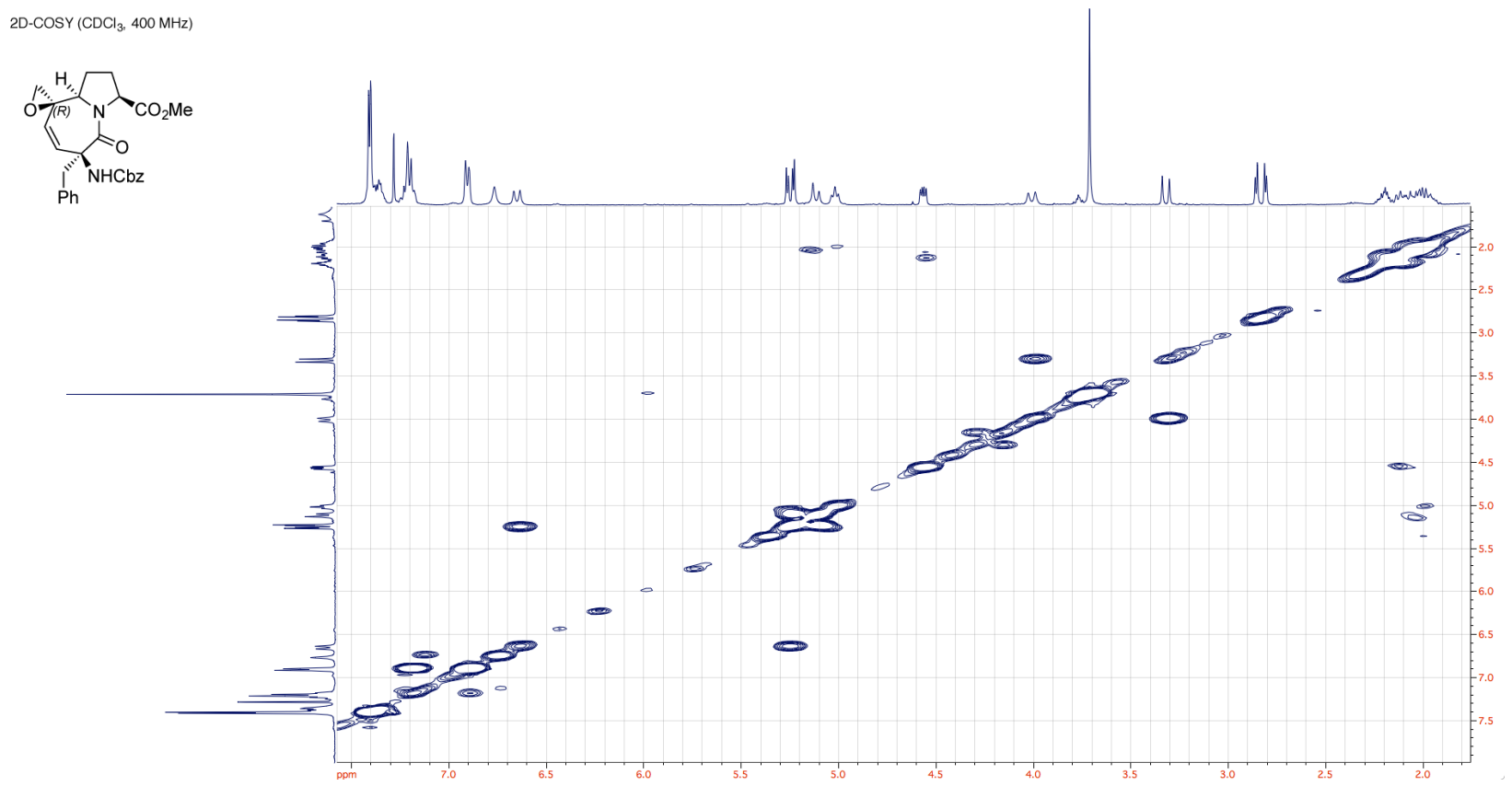

${ }^{1} \mathrm{H} \mathrm{NMR}\left(\mathrm{CDCl}_{3}, 400 \mathrm{MHz}\right)$

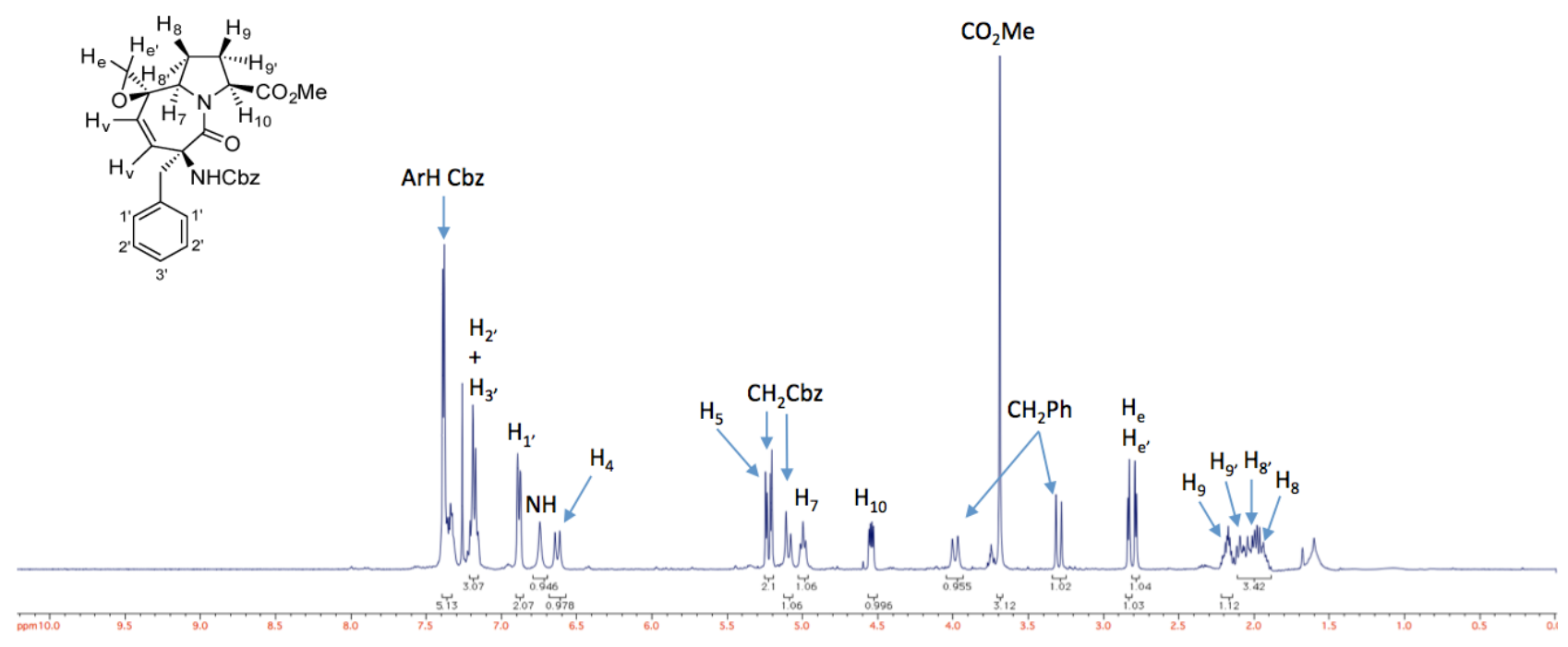


Compound 16ad: determination of absolute configuration at $\mathrm{C6}$

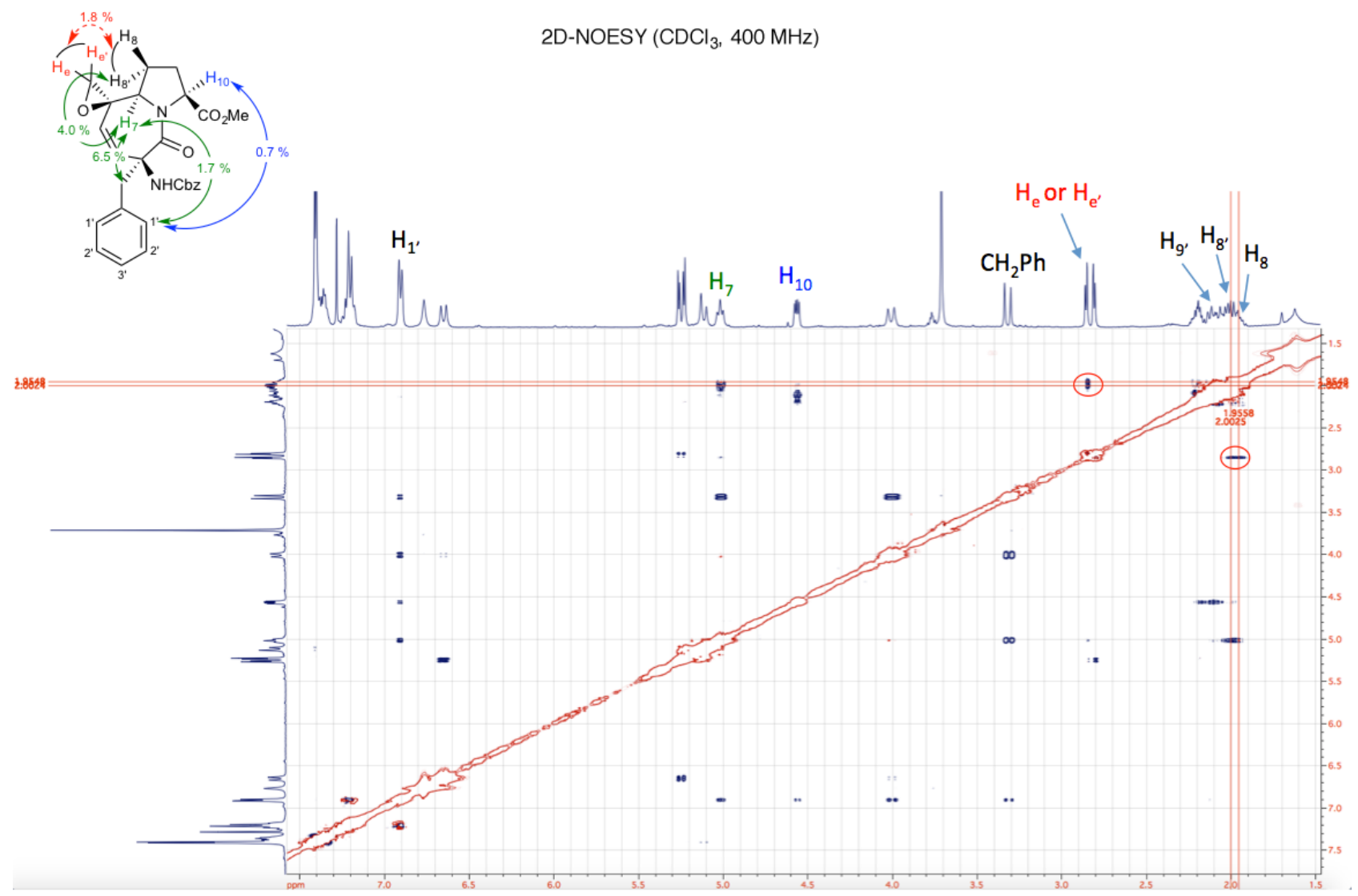

Curved arrows: NOESY correlations observed for $16 \mathrm{ad}$.

The absolute configuration at $\mathrm{C} 7$ and $\mathrm{C} 10$ was confirmed by NOE correlations between $\mathrm{H}_{7}$ and one of the benzylic protons, $\mathrm{H}_{7}$ and $\mathrm{H}_{1}$, and $\mathrm{H}_{10}$ and $\mathrm{H}_{1}$. The $R$-configuration of the newly created quaternary stereocenter at C6 was carried out by comparing the 2D-NOESY spectrum of 16ad with that of 16au (see page S19). In 16ad one proton of the epoxide ring $\left(\mathrm{H}_{e}\right.$ or $\mathrm{H}_{\mathrm{e}}$ ) established weak NOE contacts with both $\mathrm{H}_{8}$ protons, while no NOEs with $\mathrm{H}_{9}$ were observed. 
${ }^{1}$ H NMR (400 MHz), ${ }^{13} \mathrm{C}$ NMR, DEPT 135, 2D-COSY, 2D-NOESY, 2D-HMQC, and 2DHMBC spectra for compound 16au

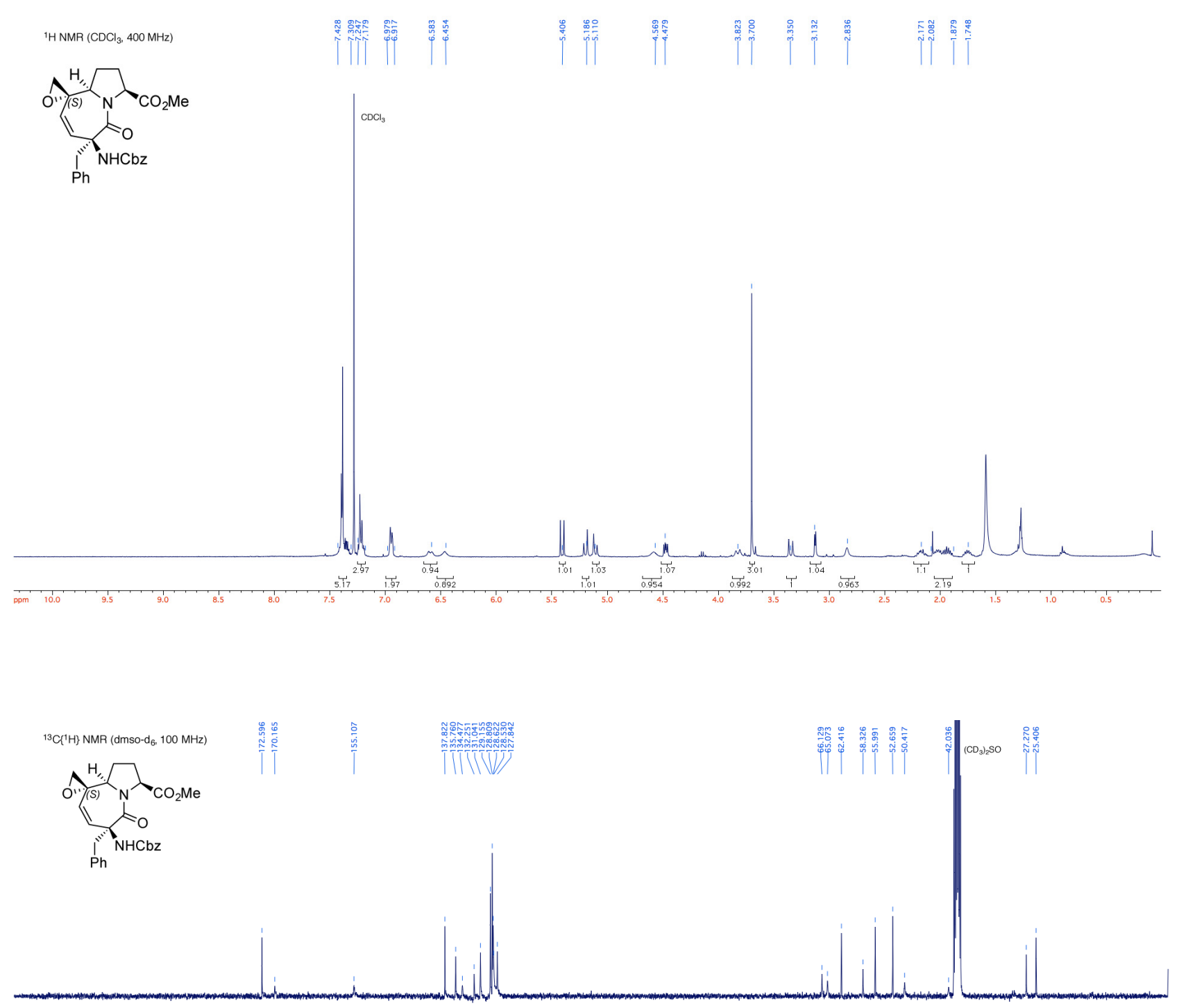

DEPT-135 (dmso-d $6.100 \mathrm{MHz})$

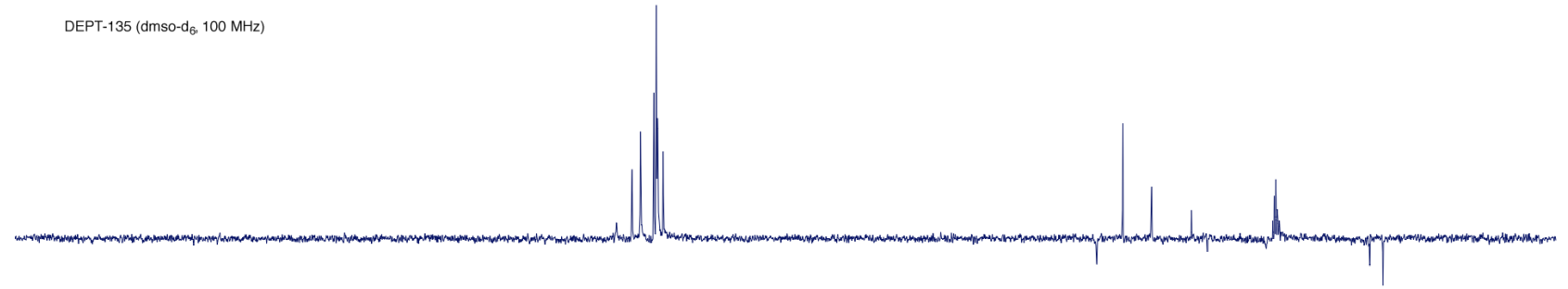



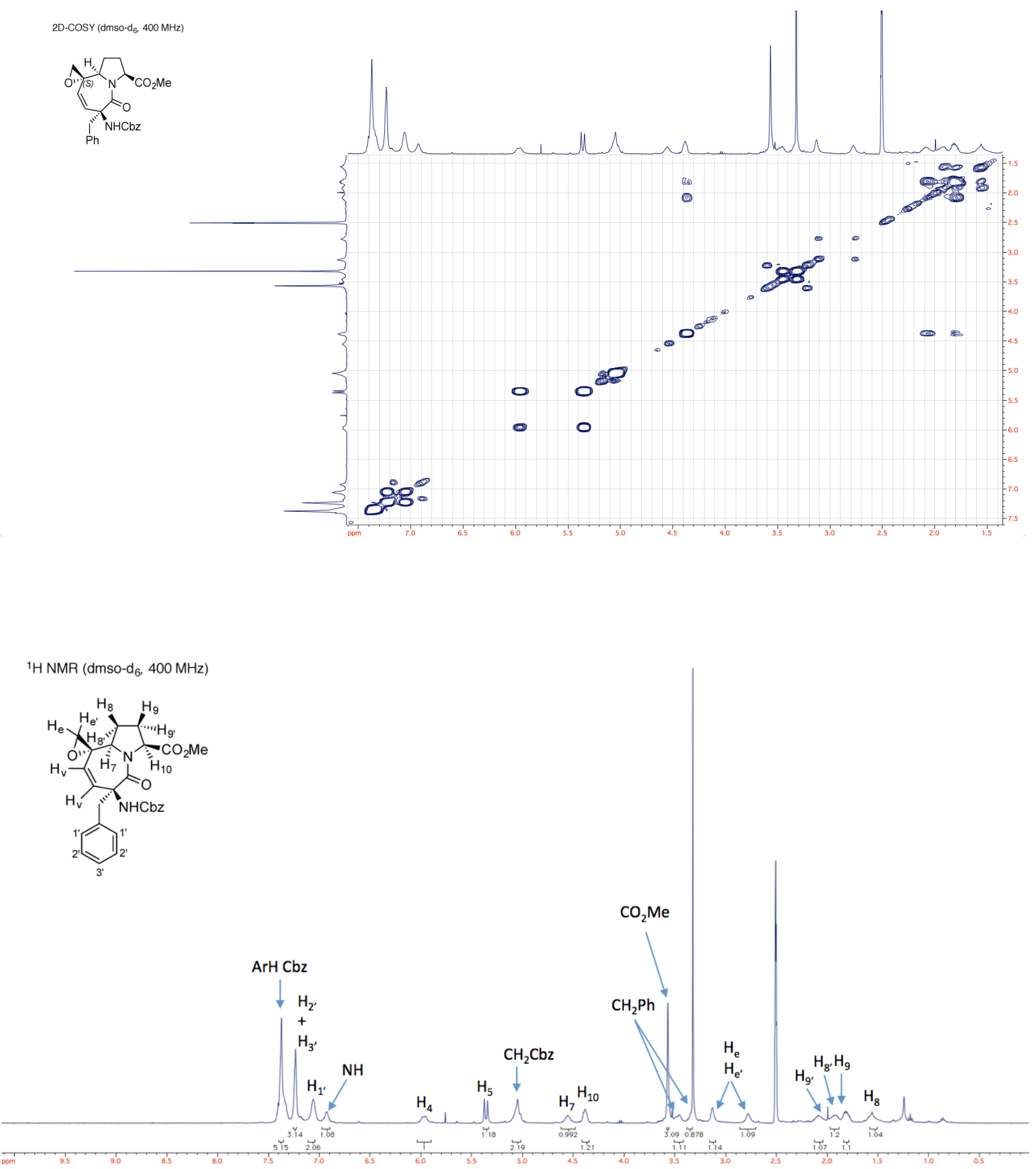


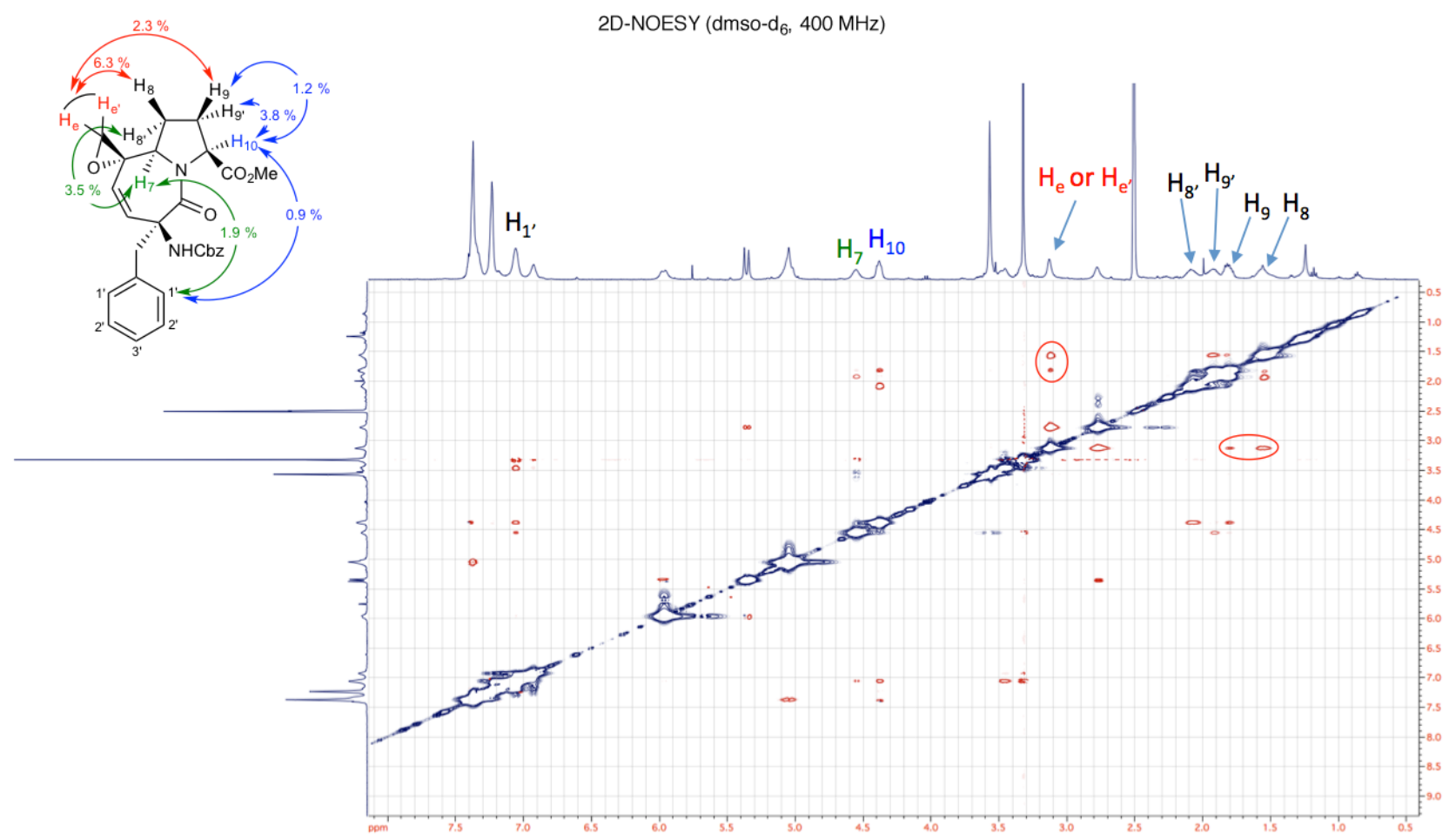

Curved arrows: NOESY correlations observed for 16au.

The absolute configuration at C7 and C10 was confirmed by NOE correlations between $\mathrm{H}_{7}$ and $\mathrm{H}_{10}$ with $\mathrm{H}_{1}$. The strong magnetization transfer between one of the epoxide protons $\left(\mathrm{H}_{\mathrm{e}}\right.$ or $\mathrm{H}_{\mathrm{e}}$ ) and $\mathrm{H}_{8}$, along with the NOE correlation with $\mathrm{H}_{9}$, indicates that the methylene group of the oxirane ring points above the molecular plane and, accordingly, the absolute configuration of the quaternary stereocenter at C6 is $S$. 

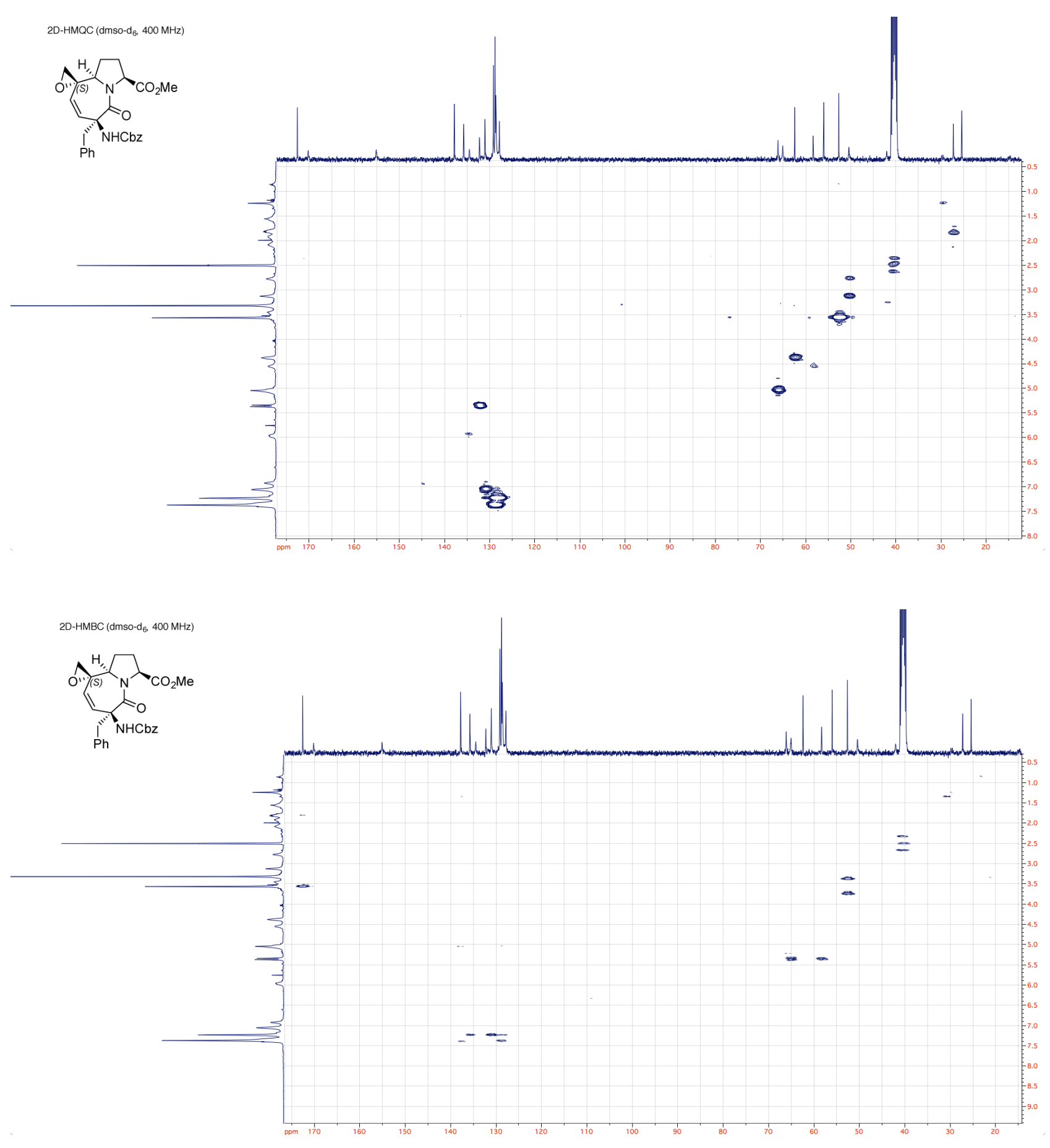
${ }^{1} \mathrm{H}$ NMR (400 MHz), ${ }^{13} \mathrm{C}$ NMR, DEPT 135, 2D-COSY, 2D-NOESY, and 2D-HMQC spectra for compound 18a
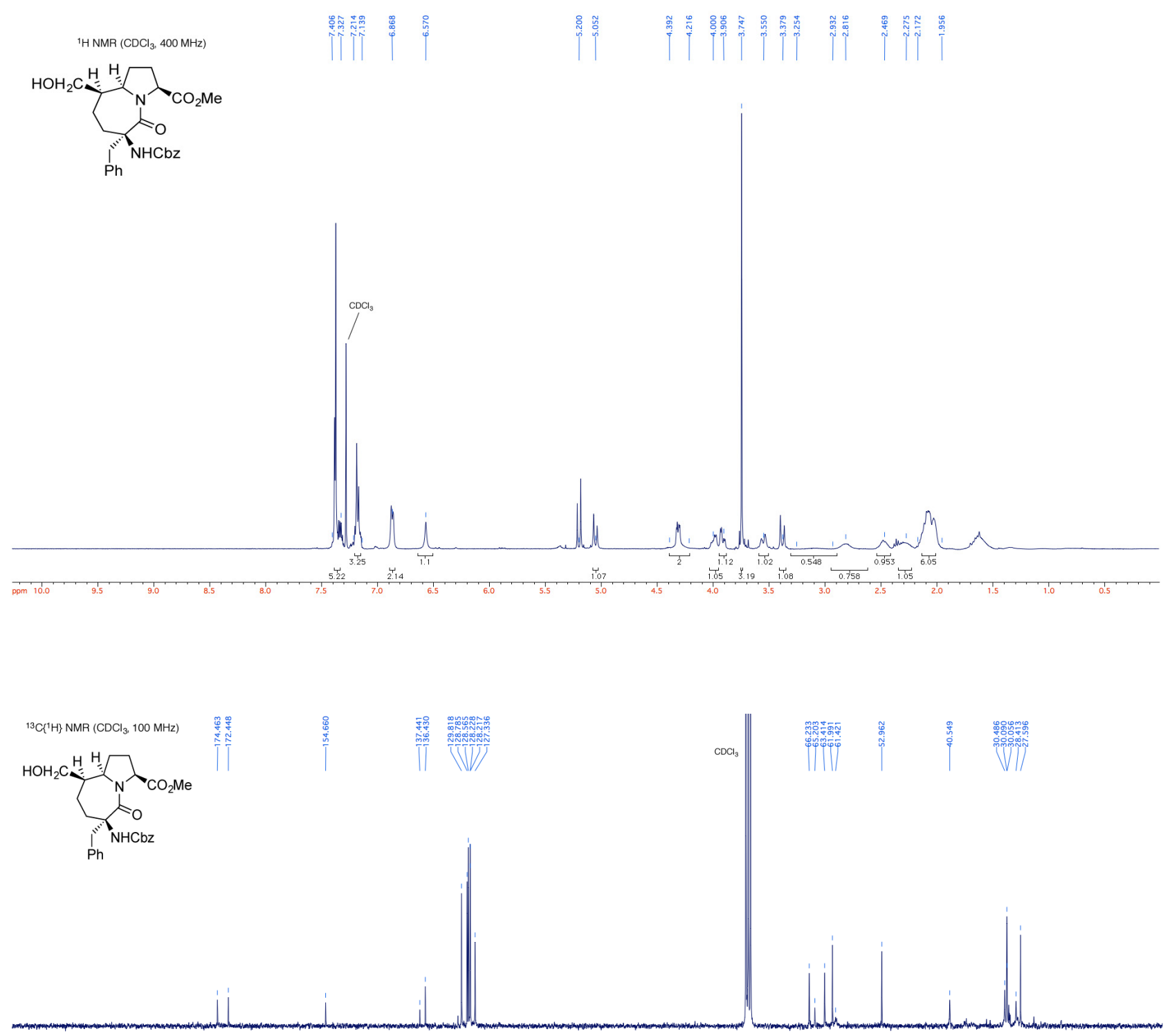

DEPT-135 (CDCl $3,100 \mathrm{MHz})$

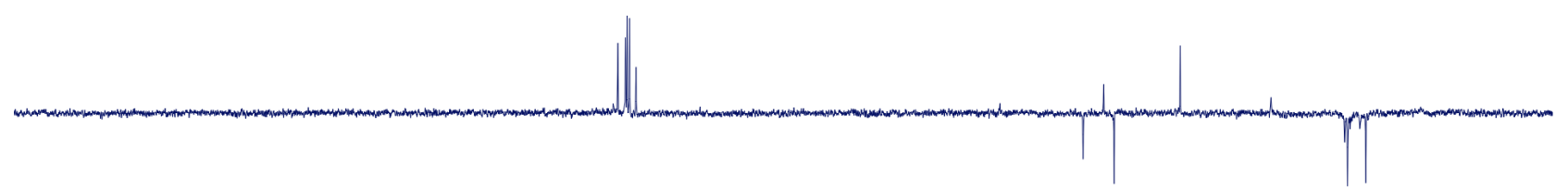



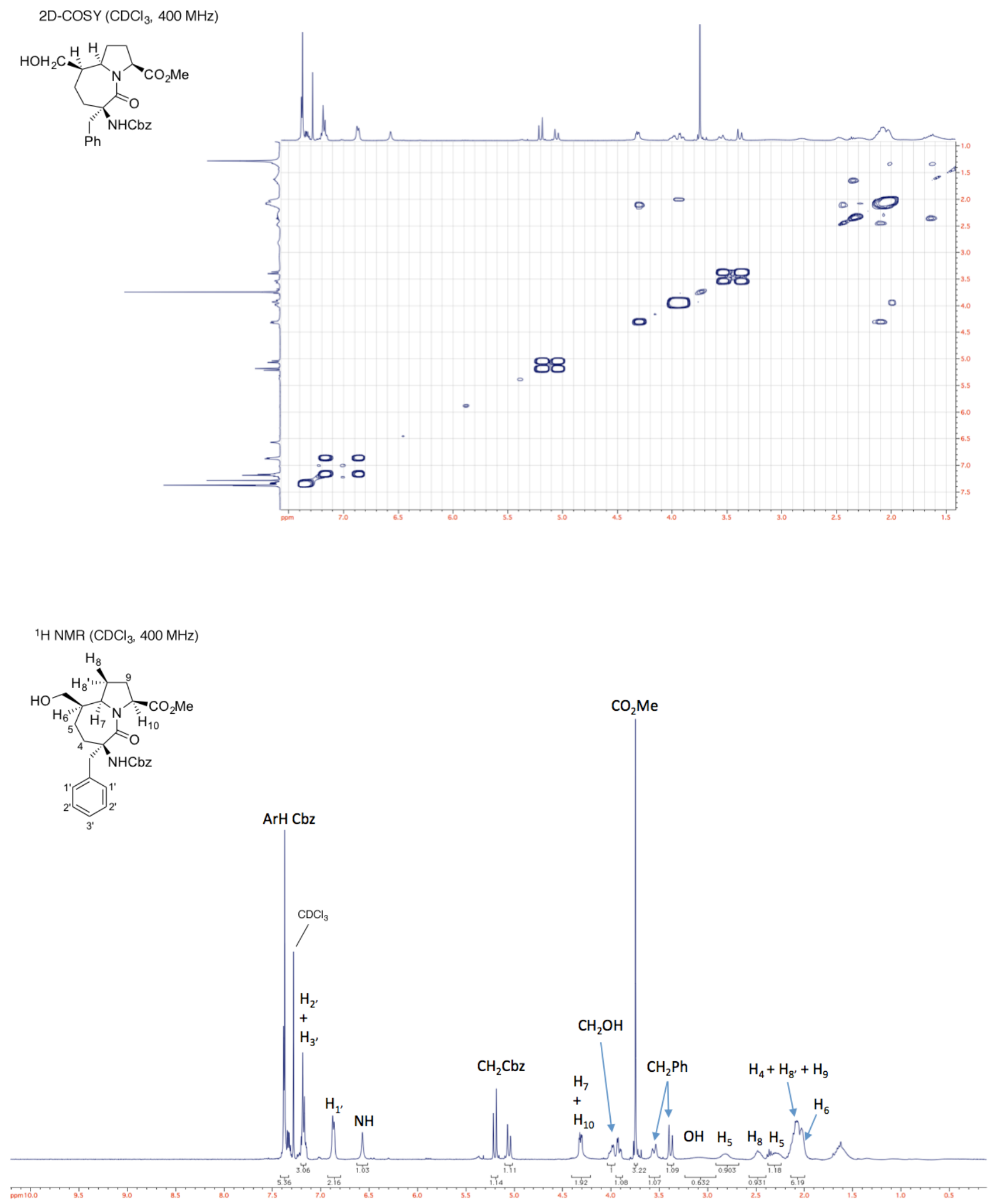


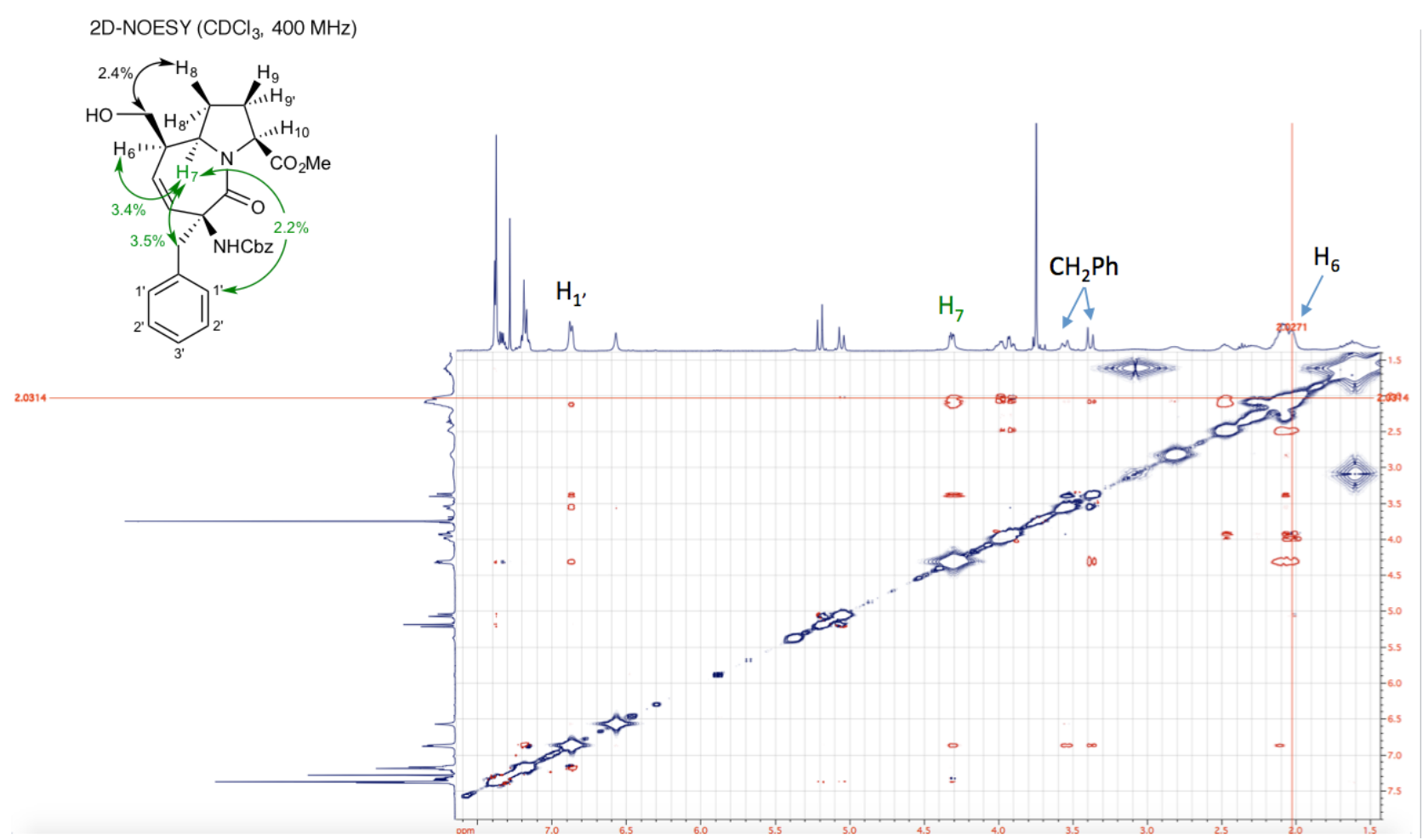

Curved arrows: NOESY correlations observed for $18 \mathrm{a}$.

The absolute configuration at $\mathrm{C} 7$ was confirmed by NOE correlations between $\mathrm{H}_{7}$ and one of the benzylic protons, and between $\mathrm{H}_{7}$ and $\mathrm{H}_{1}$. Diagnostic for the absolute $R$-configuration at $\mathrm{C} 6$ is the presence of an NOE between $\mathrm{H}_{6}$ and $\mathrm{H}_{7}$. This data was in agreement with the results previously reported by us $^{1}$ and by Lubell's group ${ }^{2}$ on similar azabicycloalkane scaffolds. Indeed, it has been observed that a magnetization transfer between vicinal protons only occurred when the vicinal protons were oriented toward the same side of the seven-membered lactam ring.

(1) Serra, M.; Peviani, E. G.; Bernardi, E.; Colombo, L. J. Org. Chem. 2017, 82, 11091-11101.

(2) Godina, T. A.; Lubell, W. D. J. Org. Chem. 2011, 76, 5846- 5849. 


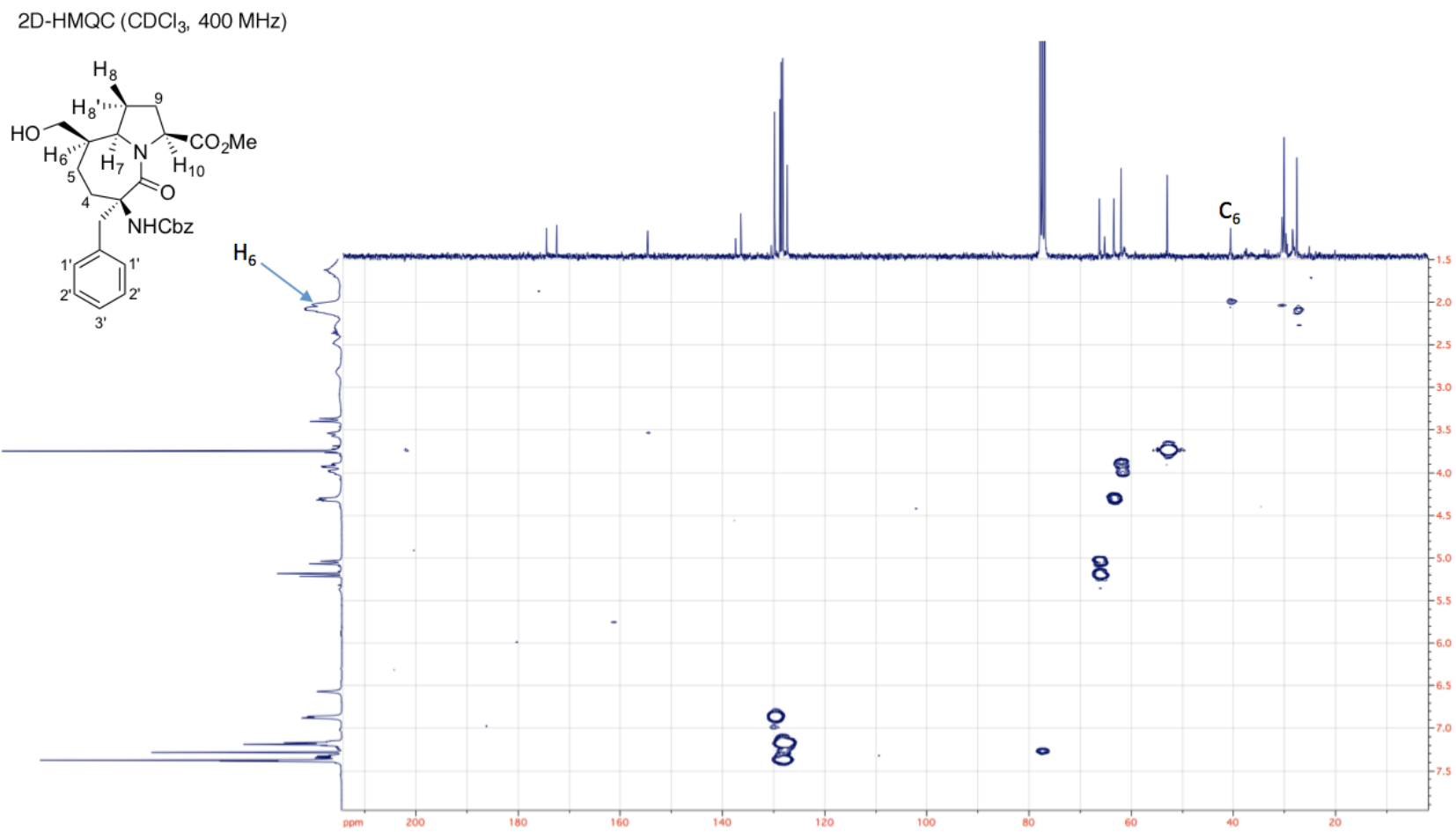




\section{${ }^{1} \mathrm{H}$ NMR (400 MHz) spectra of side product I}
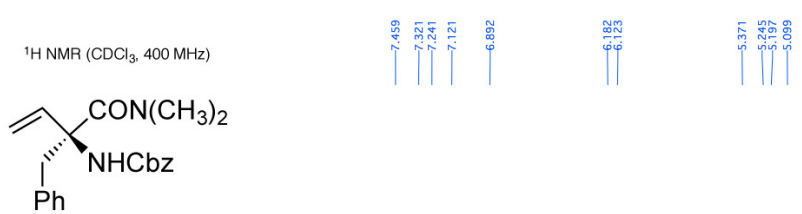

$\mathrm{Ph}$

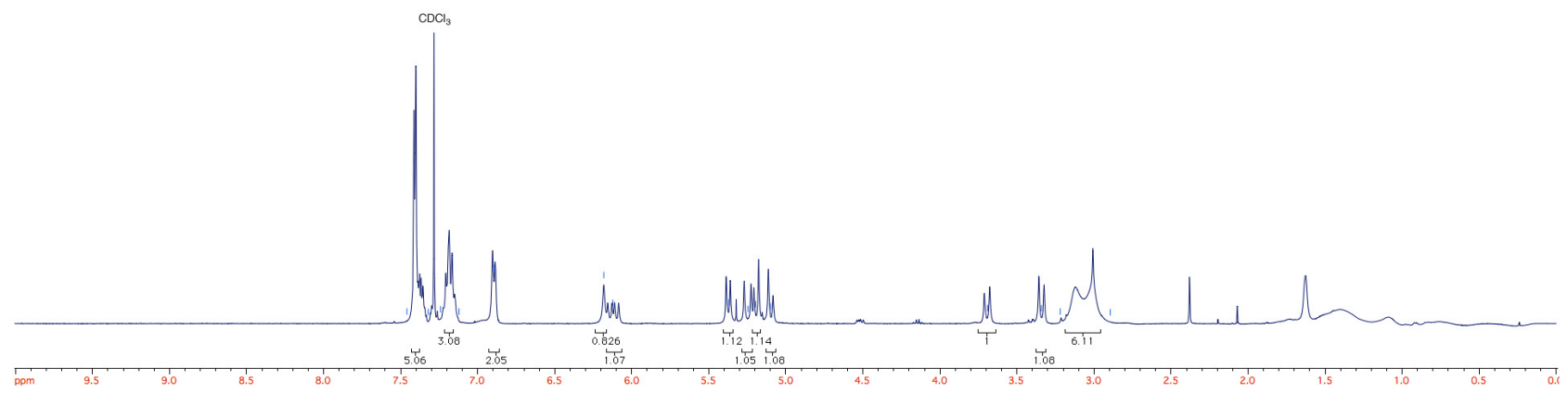

${ }^{1} \mathrm{H}$ NMR $\left(\mathrm{CDCl}_{3}, 400 \mathrm{MHz}\right) \delta$ 2.89-3.22 (br, 6H), $3.34(\mathrm{~d}, J=13.7 \mathrm{~Hz}, 1 \mathrm{H}), 3.69$ (d, $J=13.8 \mathrm{~Hz}$, $1 \mathrm{H}), 5.10(\mathrm{~d}, J=12.4 \mathrm{~Hz}, 1 \mathrm{H}), 5.20(\mathrm{~d}, J=12.3 \mathrm{~Hz}, 1 \mathrm{H}), 5.25(\mathrm{~d}, J=17.6 \mathrm{~Hz}, 1 \mathrm{H}), 5.37(\mathrm{~d}, J=$ $10.7 \mathrm{~Hz}, 1 \mathrm{H}), 6.12(\mathrm{dd}, J=10.7,17.6 \mathrm{~Hz}, 1 \mathrm{H}), 6.18(\mathrm{~s}, 1 \mathrm{H}), 6.89(\mathrm{~d}, J=6.8 \mathrm{~Hz}, 2 \mathrm{H}), 7.12-7.24$ (m, $3 \mathrm{H}), 7.32-7.46(\mathrm{~m}, 5 \mathrm{H})$. 

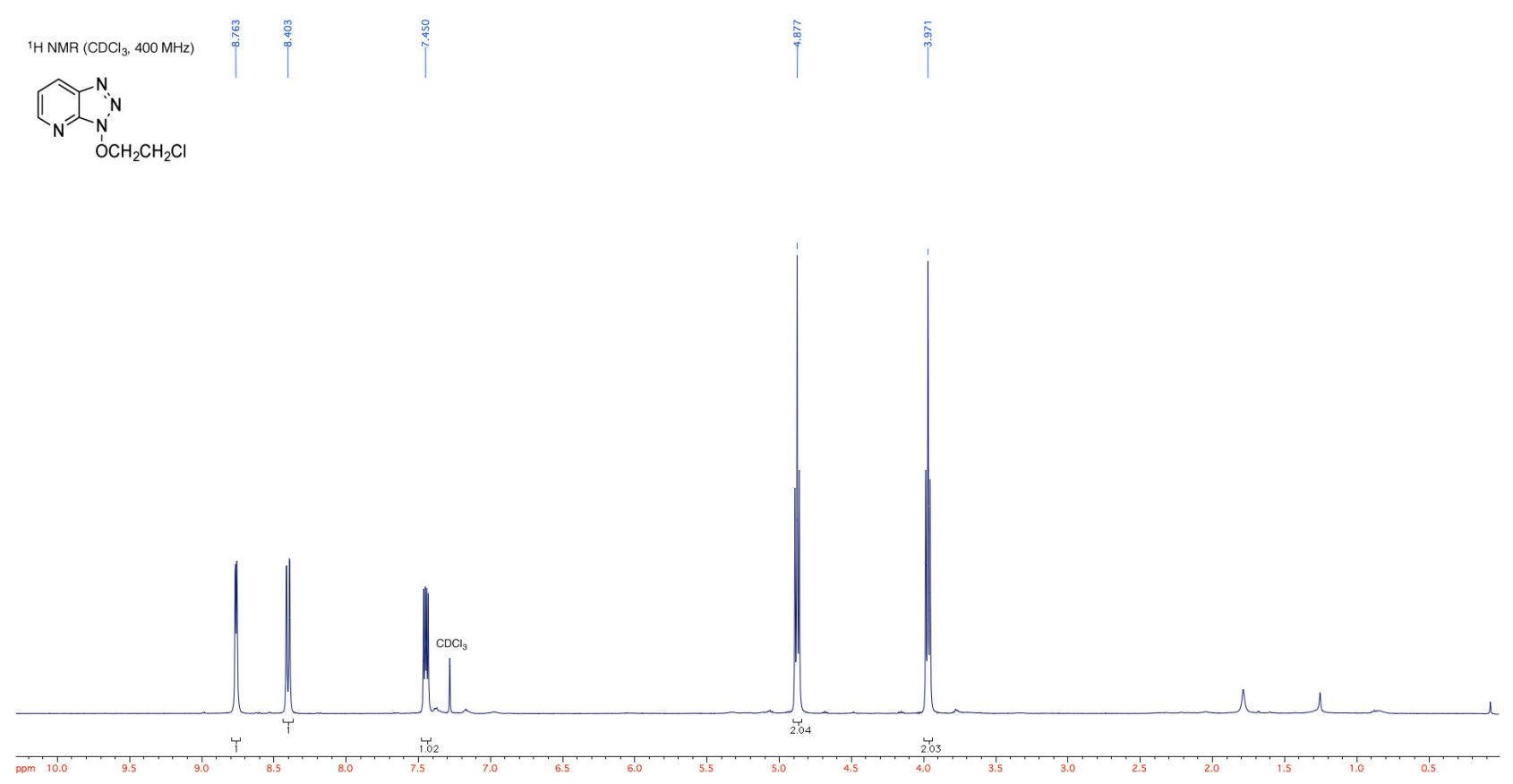

$\left.{ }^{13} \mathrm{C}^{1} \mathrm{H}\right\} \mathrm{NMR}\left(\mathrm{CDCl}_{3}, 100 \mathrm{MHz}\right)$

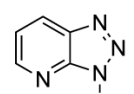

$\mathrm{OCH}_{2} \mathrm{CH}_{2} \mathrm{Cl}$
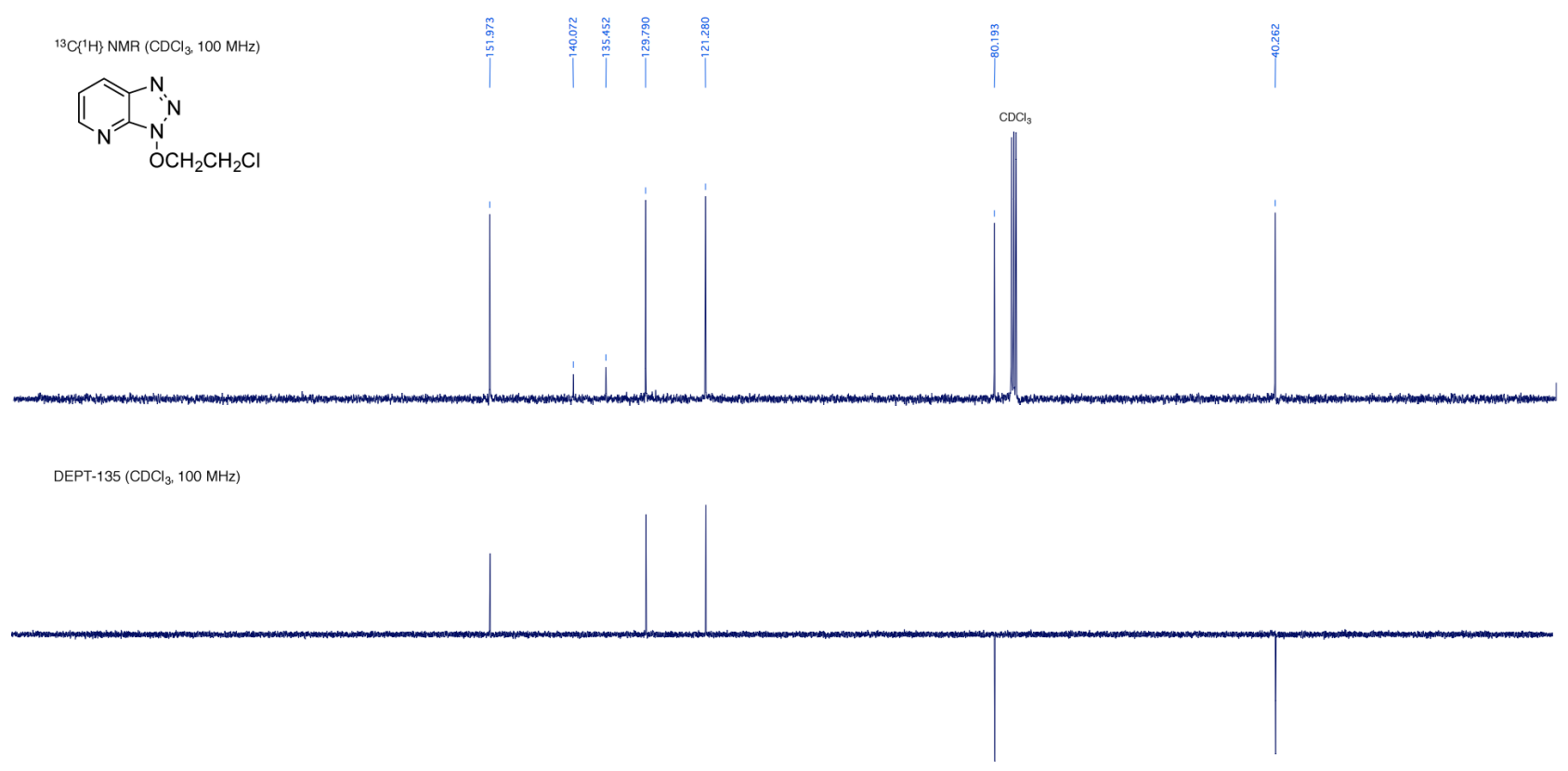

${ }^{1} \mathrm{H} \mathrm{NMR}\left(\mathrm{CDCl}_{3}, 400 \mathrm{MHz}\right) \delta 3.97(\mathrm{t}, J=6.0 \mathrm{~Hz}, 2 \mathrm{H}), 4.88(\mathrm{t}, J=6.0 \mathrm{~Hz}, 2 \mathrm{H}), 7.45(\mathrm{dd}, J=4.5$, $8.4 \mathrm{~Hz}, 1 \mathrm{H}), 8.40(\mathrm{dd}, J=1.1,8.4 \mathrm{~Hz}, 1 \mathrm{H}), 8.76(\mathrm{dd}, J=1.3,4.5 \mathrm{~Hz}, 1 \mathrm{H}) ;{ }^{13} \mathrm{C}\left\{{ }^{1} \mathrm{H}\right\} \mathrm{NMR}\left(\mathrm{CDCl}_{3}\right.$, $100 \mathrm{MHz}) \delta 40.3(\mathrm{t}), 80.2(\mathrm{t}), 121.3,129.8,135.5(\mathrm{~s}), 140.1(\mathrm{~s}), 152.0$ 